\title{
Are Glacials Dry? Consequences for Paleoclimatology and for Greenhouse Warming $\mathscr{O}$
}

\author{
JACOB ScheFF, Richard SEAGER, AND Haibo LiU \\ Lamont-Doherty Earth Observatory, Columbia University, Palisades, New York \\ SLOAN COATS \\ Cooperative Institute for Research in Environmental Sciences, University of Colorado Boulder, \\ and National Center for Atmospheric Research, Boulder, Colorado
}

(Manuscript received 29 November 2016, in final form 1 April 2017)

\begin{abstract}
Past cold climates are often thought to have been drier than today on land, which appears to conflict with certain recent studies projecting widespread terrestrial drying with near-future warming. However, other work has found that, over large portions of the continents, the conclusion of future drying versus wetting strongly depends on the physical property of interest. Here, it is shown that this also holds in simulations of the Last Glacial Maximum (LGM): the continents have generally wetter topsoils and higher values of common climate wetness metrics than in the preindustrial, as well as generally lower precipitation and ubiquitously lower photosynthesis (likely driven by the low $\mathrm{CO}_{2}$ ), with streamflow responses falling in between. Using a large existing global pollen and plant fossil compilation, it is also confirmed that LGM grasslands and open woodlands grew at many sites of present-day forest, seasonal forests at many sites of present-day rain forest, and so forth (116-144 sites out of 302), while changes in the opposite sense were very few (9-17 sites out of 302 ) and spatially confined. These vegetation changes resemble the model photosynthesis responses but not the hydroclimate responses, while published lake-level changes resemble the latter but not the former. Thus, confidence in both the model hydrologic and photosynthesis projections is increased, and there is no significant conflict. Instead, paleo- and modern climate researchers must carefully define "wetting" and "drying" and, in particular, should not assume hydrologic drying on the basis of vegetation decline alone or assume vegetation stress on the basis of declines in hydroclimatic indicators.
\end{abstract}

\section{Introduction}

Global cold climates of the recent past, such as the Last Glacial Maximum (LGM; 23000-19000 yr ago), are often described as dry or arid on land (with a few regional exceptions). This characterization has been made on the basis of sparse or treeless vegetation (Hegerl et al. 2007; Prentice et al. 2000; Adams and Faure 1997), high dust deposition (Petit et al. 1999; Muhs 2013), and a range of other evidence as summarized by Williams (2014, section 12.8). Such "glacial aridity" is frequently assumed to be the simple

Supplemental information related to this paper is available at the Journals Online website: http://dx.doi.org/10.1175/ JCLI-D-16-0854.s1.

Corresponding author: Jacob Scheff, jscheff@uncc.edu consequence of colder temperatures and/or lower absolute humidities leading to a weakened water cycle (e.g., Muhs 2013; Feakins and deMenocal 2010; Adams and Faure 1997). Similarly, past warm greenhouse climates are often described as wet (e.g., Boucot et al. 2013; Sloan et al. 1992), so that the cooling into our current icehouse is negatively labeled a climatic "deterioration" (e.g., Frakes et al. 1992).

Yet, in atmospheric science, it is not thought that climates generally become wetter with warming. First, it is well understood that global-average precipitation $P$ scales with Earth's energy budget rather than with atmospheric humidity so that its increase is actually quite small (e.g., Held and Soden 2006; Stephens and Hu 2010; Pendergrass and Hartmann 2014). Instead, precipitation responses to greenhouse warming in climate models and modern observations are dominated by regional signals of varying sign, particularly at low to midlatitudes (e.g., Roderick 
et al. 2014; Byrne and O'Gorman 2015; Greve and Seneviratne 2015; Greve et al. 2014; Scheff and Frierson 2015). At the same time, physically computed evaporative demand or potential evapotranspiration (PET) robustly increases with warming (e.g., Scheff and Frierson 2014; Valipour et al. 2017). Thus, climatic wetness metrics like the aridity index (P/PET), Palmer drought severity index (PDSI), and standardized precipitation evapotranspiration index (SPEI) robustly decline with greenhouse warming over much of Earth's land (e.g., Feng and Fu 2013; Fu and Feng 2014; Cook et al. 2014; Scheff and Frierson 2015; Zhao and Dai 2015, 2017), with far fewer regions of wetting. At face value this would all seem to imply a contradiction or tension between paleo- and future-climate conclusions [section 5.1 of Scheff (2014); Roderick et al. 2015; Scheff and Frierson 2015], though Broecker (2010) has suggested that regional LGM hydroclimates were wetter than implied by the above studies.

However, it is now emerging (e.g., Swann et al. 2016; Fu et al. 2016, end of section 6) that the sign and nature of the local land wetness response to modeled warming strongly depends on what actual property is meant by "wetness." Topsoil moisture (Collins et al. 2013; Dai 2013) and boundary layer relative humidity (Collins et al. 2013; Sherwood and $\mathrm{Fu} 2014$ ) are projected to robustly decline across most of the tropics, subtropics, and midlatitudes, with nearly the same spatial pattern as the above indexbased drying. Yet, runoff production and/or precipitation minus evaporation $(P-E)$ respond more like precipitation, with regions of decrease and increase (Seager et al. 2010; Collins et al. 2013; Roderick et al. 2014; Milly and Dunne 2016) and no sense of global drying or wetting, as the water-resources community has long understood (e.g., Arnell et al. 2001). (Precipitation minus evaporation is nearly equal to surface plus subsurface runoff production or streamflow plus aquifer recharge on these time scales in most regions, so these will be used interchangeably here.) Furthermore, photosynthesis, another primary motivation for the drought and aridity indices, robustly increases, as modeled $\mathrm{CO}_{2}$ fertilization overwhelms any effects of the hydroclimate changes (Arora et al. 2013; Shao et al. 2013; Roderick et al. 2015).

Thus, at least in GCMs, greenhouse warming at any one location can cause "wetting" or "drying," depending on the definition of "aridity" employed. To some extent these divergences are expected from land surface physics (e.g., in a dry region with $P-E \sim 0$, soil moisture can decline with increasing PET, even with little change in $P-E$ ). However, mechanisms for these differences could also include $\mathrm{CO}_{2}$ effects on transpiration (Roderick et al. 2015; Swann et al. 2016; Berg et al. 2016; Milly and Dunne 2016), increases in precipitation intensity (e.g., Zhao and Dai 2015), and increases in precipitation seasonality.
Does this more subtle idea of land eco-hydrologic response to temperature change also apply to the past, calling into question the notion of a generally dry Last Glacial Maximum? The LGM was several degrees colder than present nearly worldwide and had much lower $\mathrm{CO}_{2}$, $\mathrm{CH}_{4}$, and $\mathrm{N}_{2} \mathrm{O}$ and more extensive ice, yet nearly the same orbit and insolation as today (e.g., MassonDelmotte et al. 2013), making it a potential antianalog for future warming. Thus, one might hypothesize that low- to midlatitude LGM topsoils, boundary layer relative humidities, and climate indices were in fact mostly wetter than today, yet stream and groundwater $(P-E)$ changes were heterogeneous, while vegetation was ubiquitously reduced owing to the low $\mathrm{CO}_{2}$. In fact, before glacials were thought of as dry (i.e., before 1970 or so), they were actually assumed to be wet or "pluvial" (Williams 2014, section 12.5 and references therein). Gerhart and Ward (2010) as well as Prentice and Harrison (2009), Prentice et al. (2011), and Bragg et al. (2013) have also strongly argued that declines in vegetation at the LGM were driven by $\mathrm{CO}_{2}$ scarcity, more so than by water scarcity.

However, two questions need to be answered about this hypothesis. First, do GCM simulations of the LGM actually obtain this combination of eco-hydrologic responses? After all, one cannot assume the LGM simulations will be perfect antianalogs of the future simulations, as the LGM includes large forcings not present in the future runs (ice-sheet effects and continental-shelf exposure), and nonlinearity could also be important. However, variables like soil moisture, photosynthesis, and PDSI have been scarcely examined in LGM simulations.

Second, and more importantly, are the observed paleoecologic and paleohydrologic records of the LGM consistent with the LGM model results? That is, did LGM vegetation look like the simulated LGM photosynthesis, and did LGM rivers and lakes look like the simulated LGM $P-E$ ? Prentice et al. (2011) drove a vegetation model with $\mathrm{LGM} \mathrm{CO}_{2}$ and several GCM estimates of LGM minus preindustrial changes in temperature, precipitation, and sunshine hours and compared the predicted LGM biomes to a pollen and fossil compilation. They found broad agreement, supporting the above hypothesis. Yet they did not attempt to verify the GCMs' own eco-hydrologic projections.

Thus, in this study, we analyze the latest LGM multiGCM output (Taylor et al. 2012; Braconnot et al. 2012) to answer the first question above (strongly in the affirmative) and begin to answer the second question (affirmative, so far) by direct comparisons of a standard pollen and plant fossil compilation to the GCM variables analyzed. Future work will more fully answer the second question for hydrology (e.g., lake-level proxies) 
as well and will further explore the reason(s) for the complex GCM hydrologic responses. This inquiry will greatly sharpen interpretations of paleoclimate proxies, expectations of the eco-hydrologic impacts of future climate change, and our assessment of the qualitative performance of comprehensive GCMs.

\section{Methods}

\section{a. Model analysis}

We examine LGM and matching preindustrial control simulations from all nine available models (Table 1, above the blank row) in phase 5 of the Coupled Model Intercomparison Project (CMIP5; Taylor et al. 2012) and/or phase 3 of the Paleoclimate Modelling Intercomparison Project (PMIP3; Braconnot et al. 2012), which are largely synonymous for these experiments. Run " 1 1" with configuration " $p 1$," usually the only run available for the LGM, is used except where noted below. The LGM runs simulate a $100-\mathrm{yr}$ time slice at $21000 \mathrm{yr}$ before present, using standard prescribed estimates of the greenhouse gas levels, ice sheet geometry, land-sea geography, and insolation at that time but preindustrial vegetation and dust (https://wiki.lsce.ipsl.fr/pmip3/doku. php/pmip3:design:21k:final). For GISS-E2-R, the North American ice sheet is actually $\approx 1 \mathrm{~km}$ higher (configuration $\mathrm{p} 150$ ) or lower (configuration p151) than the standard (Ullman et al. 2014); our results for the two are nearly identical outside the United States, so our plots include only the low-elevation version, which Ullman et al. (2014) prefer. Similarly, for MPI-ESM-P, an additional LGM configuration ( $\mathrm{p} 2$ ) with dynamic rather than prescribed vegetation is available, but our results are mostly the same as for the standard configuration (p1), so our plots include only the standard simulation.

For each variable and for each model with sufficient output (Table 1), over all model grid cells that have at least $5 \%$ ice-free land in both periods, the LGM response is computed as the annual mean over the entire LGM run minus the annual mean over the entire preindustrial control run. (Most of the results cited in section 1 are also annual mean.) These means are computed from monthly output, weighted by month length. For precipitation and $P-E$, this is straightforward. Topsoil moisture ("mrsos" in the CMIP5 data) is given as kilograms per square meter (i.e., $\mathrm{mm}$ ) of water in a surface soil layer of fixed depth; we normalize by that depth (10 mm in CNRM-CM5; $100 \mathrm{~mm}$ elsewhere) to obtain volumetric water content $\theta$, a more comparable metric ranging from $\theta \approx 0.05$ in deserts to $\theta \approx 0.4$ in the wettest areas. Several photosynthesis outputs are available; we use net primary productivity (NPP), because it closely corresponds to the production of plant resources for economic betterment (e.g., in pastures or forests) and also because it is strongly coupled to gross primary productivity, which equals the flux of carbon through the leaf stomata (e.g., Bonan 2008) and thus is most directly affected by water availability.

For Penman-Monteith PET, we use the monthly method of Scheff and Frierson (2015) but with vegetation height $0.12 \mathrm{~m}$ and well-watered canopy conductance $70 \mathrm{~s} \mathrm{~m}^{-1}$, to match the Food and Agriculture Organization's (FAO) FAO-56 (Allen et al. 1998) method used by Cook et al. (2014) and others. We use diurnal-mean temperature to compute the saturation vapor pressure, because the FAO-56-preferred diurnal maximum and minimum temperature fields in IPSL-CM5A are incorrect (http://errata.ipsl.upmc.fr/issue/21) and also to match earlier studies. Scheff and Frierson (2014, 2015) showed that these choices do not appreciably affect PET change projections. CCSM4 did not save near-surface wind speed, but this makes a negligible contribution to the LGM-preindustrial PET changes in all available models, so we substitute the multimodel monthly surface wind climatologies (of the LGM and of the preindustrial) in this model. Likewise, MPI-ESM-P/MPI-ESM-LR did not save near-surface specific (or relative) humidity, but near-surface dewpoint was obtained from the modeling group (T. Mauritsen 2015, personal communication), and actual vapor pressure is computed from this.

As part of the PET computation, monthly relative humidity ( $\mathrm{RH})$ is defined as monthly actual vapor pressure divided by monthly saturation vapor pressure. Because of nonlinearity, this does not strictly equal the monthly mean of RH; but we think of it as an effective relative humidity, which exactly obtains the monthly vapor pressure deficit from the monthly saturation vapor pressure in the Penman-Monteith equation.

Given the monthly $P$ and PET fields, the monthly PDSI is computed for both the LGM and the preindustrial as in Cook et al. (2014), using the entire preindustrial run as the reference period for defining the PDSI values, and averaged and differenced as above. (Using the LGM run instead for the PDSI reference/ definition period produced very similar differences.) Cook et al. (2014) found that the PDSI and the SPEI behave quite similarly with climate change, so we only considered PDSI because it is more prominent in the literature cited in section 1 . The aridity index $P / P E T$ for each experiment is computed using the climatological annual-mean $P$ and the climatological annual-mean PET, as is standard (e.g., Middleton and Thomas 1997), before differencing.

Finally, for each LGM-preindustrial difference field, the multimodel statistics are obtained by nearest-neighbor interpolating each model's estimate to a common $2^{\circ}$ grid. 
TABLE 1. CMIP5/PMIP3 GCMs used in this study, with available monthly output of precipitation and evapotranspiration, topsoil moisture (SM), necessary variables for computing Penman-Monteith PET and thus PDSI as well as near-surface RH, and NPP. Models above the blank row simulated the LGM and are used in all analyses, while models below the blank row did not simulate the LGM and are used only for Fig. A1.

\begin{tabular}{|c|c|c|c|c|c|}
\hline Model acronym & Expansion (country) & $P$ and $E$ & SM & $\begin{array}{l}\text { PET, PDSI, } \\
\text { and RH }\end{array}$ & \\
\hline $\mathrm{CCSM}^{\mathrm{a}}$ & Community Climate System Model, version 4 (United States) & Yes & Yes & Yes $^{\mathrm{b}}$ & \\
\hline CNRM-CM5 & $\begin{array}{l}\text { Centre National de Recherches Météorologiques Coupled } \\
\text { Global Climate Model, version } 5 \text { (France) }\end{array}$ & Yes & Yes & Yes & \\
\hline COSMOS-ASO ${ }^{c}$ & $\begin{array}{l}\text { Community Earth System Model }{ }^{\mathrm{d}} \text { with Atmosphere, Surface, } \\
\text { and Ocean components (Germany) }\end{array}$ & Yes & No & No & $\mathrm{N}$ \\
\hline FGOALS-g2 & $\begin{array}{l}\text { Flexible Global Ocean-Atmosphere-Land System Model, } \\
\text { gridpoint version } 2 \text { (China) }\end{array}$ & Yes & Yes & $\mathrm{No}^{\mathrm{e}, \mathrm{b}}$ & $\mathrm{N}$ \\
\hline GISS-E2- $R^{\mathrm{f}}$ & $\begin{array}{l}\text { Goddard Institute for Space Studies Model E2, coupled with } \\
\text { the Russell ocean model (United States) }\end{array}$ & Yes & Yes & Yes & $\mathrm{N}$ \\
\hline IPSL-CM5A-LR & $\begin{array}{l}\text { L'Institut Pierre-Simon Laplace Coupled Model, version 5A, } \\
\text { low resolution (France) }\end{array}$ & Yes & Yes & Yes $^{\mathrm{g}}$ & \\
\hline MIROC-ESM & $\begin{array}{l}\text { Model for Interdisciplinary Research on Climate, Earth System } \\
\text { Model (Japan) }\end{array}$ & Yes & Yes & $\mathrm{No}^{\mathrm{h}}$ & \\
\hline MPI-ESM-P ${ }^{\mathrm{i}}$ & $\begin{array}{l}\text { Max Planck Institute Earth System Model, paleoclimate } \\
\text { (Germany) }\end{array}$ & Yes & No & Yes & \\
\hline MRI-CGCM3 & $\begin{array}{l}\text { Meteorological Research Institute Coupled Atmosphere- } \\
\text { Ocean General Circulation Model, version } 3 \text { (Japan) }\end{array}$ & Yes & Yes & Yes & \\
\hline ACCESS1.0 & $\begin{array}{l}\text { Australian Community Climate and Earth-System Simulator, } \\
\text { version 1.0 (Australia) }\end{array}$ & Yes & Yes & Yes $^{\mathrm{j}}$ & \\
\hline ACCESS1.3 & $\begin{array}{l}\text { Australian Community Climate and Earth-System Simulator, } \\
\text { version } 1.3 \text { (Australia) }\end{array}$ & Yes & Yes & Yes $^{\mathrm{j}}$ & \\
\hline BCC_CSM1.1 & $\begin{array}{l}\text { Beijing Climate Center, Climate System Model, version } 1.1 \\
\text { (low resolution) (China) }\end{array}$ & Yes & Yes & Yes & \\
\hline BCC_CSM1.1(m) & $\begin{array}{l}\text { Beijing Climate Center, Climate System Model, version } 1.1 \\
\text { (moderate resolution) (China) }\end{array}$ & Yes & Yes & Yes & \\
\hline BNU-ESM & Beijing Normal University-Earth System Model (China) & Yes & Yes & Yes & \\
\hline CanESM2 & Second Generation Canadian Earth System Model (Canada) & Yes & Yes & Yes & \\
\hline CESM1(BGC) & $\begin{array}{l}\text { Community Earth System Model, version } 1 \text { (biogeochemistry, } \\
\text { or carbon cycle) (United States) }\end{array}$ & Yes & Yes & Yes $^{\mathrm{b}}$ & \\
\hline CESM1(CAM5) & $\begin{array}{l}\text { Community Earth System Model, version } 1 \text { (Community At- } \\
\text { mosphere Model, version 5) (United States) }\end{array}$ & Yes & Yes & Yes & \\
\hline CESM1(CAM5.1,FV2) ${ }^{\mathrm{k}}$ & $\begin{array}{l}\text { Community Earth System Model, version } 1 \text { (Community At- } \\
\text { mosphere Model, version 5.1, with } \approx 2^{\circ} \text { finite-volume dy- } \\
\text { namics) (United States) }\end{array}$ & Yes & No & No & \\
\hline CESM1(WACCM) ${ }^{1}$ & $\begin{array}{l}\text { Community Earth System Model, version } 1 \text { (Whole Atmo- } \\
\text { sphere Community Climate Model) (United States) }\end{array}$ & Yes & Yes & Yes $^{\mathrm{b}}$ & \\
\hline CMCC-CESM & $\begin{array}{l}\text { Centro Euro-Mediterraneo per I Cambiamenti Climatici Car- } \\
\text { bon Cycle Earth System Model (Italy) }\end{array}$ & Yes & No & No & \\
\hline CMCC-CM & $\begin{array}{l}\text { Centro Euro-Mediterraneo per I Cambiamenti Climatici Cli- } \\
\text { mate Model (Italy) }\end{array}$ & Yes & No & No & \\
\hline CMCC-CMS & $\begin{array}{l}\text { Centro Euro-Mediterraneo per I Cambiamenti Climatici } \\
\text { Stratosphere-resolving Climate Model (Italy) }\end{array}$ & Yes & No & No & \\
\hline CSIRO Mk3.6.0 & $\begin{array}{l}\text { Commonwealth Scientific and Industrial Research Organisa- } \\
\text { tion Mark 3.6.0 (Australia) }\end{array}$ & Yes & Yes & Yes & \\
\hline EC-Earth & European Consortium Earth System Model (Europe) & Yes & No & No & $\mathrm{N}$ \\
\hline FGOALS-s $2^{1}$ & $\begin{array}{l}\text { Flexible Global Ocean-Atmosphere-Land System Model, } \\
\text { second spectral version (China) }\end{array}$ & Yes & Yes & Yes & \\
\hline FIO-ESM & First Institute of Oceanography Earth System Model (China) & Yes & No & Yes $^{\mathrm{b}}$ & $\mathrm{No}$ \\
\hline GFDL CM3 & $\begin{array}{l}\text { Geophysical Fluid Dynamics Laboratory Climate Model, ver- } \\
\text { sion } 3 \text { (United States) }\end{array}$ & Yes & Yes & Yes & \\
\hline GFDL-ESM2G & $\begin{array}{l}\text { Geophysical Fluid Dynamics Laboratory Earth System Model } \\
\text { with GOLD component (United States) }\end{array}$ & Yes & Yes & Yes & \\
\hline GFDL-ESM2M & $\begin{array}{l}\text { Geophysical Fluid Dynamics Laboratory Earth System Model } \\
\text { with MOM, version } 4 \text { component (United States) }\end{array}$ & Yes & Yes & Yes & \\
\hline
\end{tabular}




\begin{tabular}{|c|c|c|c|c|c|}
\hline Model acronym & Expansion (country) & $P$ and $E$ & SM & $\begin{array}{l}\text { PET, PDSI, } \\
\text { and RH }\end{array}$ & NPP \\
\hline GISS-E2-H & $\begin{array}{l}\text { Goddard Institute for Space Studies Model E2, coupled with } \\
\text { HYCOM (United States) }\end{array}$ & Yes & Yes & Yes & Yes \\
\hline GISS-E2-H-CC & $\begin{array}{l}\text { Goddard Institute for Space Studies Model E2, coupled with } \\
\text { HYCOM and interactive terrestrial carbon cycle (and oce- } \\
\text { anic biogeochemistry) (United States) }\end{array}$ & Yes & Yes & Yes & Yes \\
\hline GISS-E2-R-CC & $\begin{array}{l}\text { Goddard Institute for Space Studies Model E2, coupled with } \\
\text { the Russell ocean model and interactive terrestrial carbon } \\
\text { cycle (and oceanic biogeochemistry) (United States) }\end{array}$ & Yes & Yes & Yes & Yes \\
\hline HadGEM2-AO & $\begin{array}{l}\text { Hadley Centre Global Environment Model, version 2, A and O } \\
\text { configurations (United Kingdom) }\end{array}$ & Yes $^{\mathrm{m}}$ & No & Yes $^{\mathrm{j}}$ & No \\
\hline HadGEM2-CC & $\begin{array}{l}\text { Hadley Centre Global Environment Model, version 2, Carbon } \\
\text { Cycle (United Kingdom) }\end{array}$ & Yes & Yes & $\mathrm{Yes}^{\mathrm{j}}$ & Yes \\
\hline HadGEM2-ES & $\begin{array}{l}\text { Hadley Centre Global Environment Model, version 2, Earth } \\
\text { System (United Kingdom) }\end{array}$ & Yes & Yes & Yes $^{\mathrm{j}}$ & Yes \\
\hline INM-CM4.0 & $\begin{array}{l}\text { Institute of Numerical Mathematics Coupled Model, version } \\
\text { 4.0 (Russia) }\end{array}$ & Yes & Yes & Yes & No \\
\hline IPSL-CM5A-MR & $\begin{array}{l}\text { L'Institut Pierre-Simon Laplace Coupled Model, version 5A, } \\
\text { mid resolution (France) }\end{array}$ & Yes & Yes & Yes & Yes \\
\hline IPSL-CM5B-LR & $\begin{array}{l}\text { L'Institut Pierre-Simon Laplace Coupled Model, version 5B, } \\
\text { low resolution (France) }\end{array}$ & Yes & Yes & Yes & Yes \\
\hline MIROC-ESM-CHEM & $\begin{array}{l}\text { Model for Interdisciplinary Research on Climate, Earth System } \\
\text { Model, Chemistry Coupled (Japan) }\end{array}$ & Yes & Yes & $\mathrm{No}^{\mathrm{h}}$ & Yes \\
\hline MIROC5 & $\begin{array}{l}\text { Model for Interdisciplinary Research on Climate, version } 5 \\
\text { (Japan) }\end{array}$ & Yes & Yes & $\mathrm{No}^{\mathrm{h}}$ & No \\
\hline MPI-ESM-MR & $\begin{array}{l}\text { Max Planck Institute Earth System Model, medium resolution } \\
\text { (Germany) }\end{array}$ & Yes & No & No & Yes \\
\hline MRI-ESM1 & $\begin{array}{l}\text { Meteorological Research Institute Earth System Model, ver- } \\
\text { sion } 1 \text { (Japan) }\end{array}$ & Yes & Yes & Yes & Yes \\
\hline NorESM1-M & $\begin{array}{l}\text { Norwegian Earth System Model, version } 1 \text { (intermediate res- } \\
\text { olution) (Norway) }\end{array}$ & Yes & Yes & Yes $^{\mathrm{b}}$ & Yes \\
\hline NorESM1-ME & $\begin{array}{l}\text { NorESM1-M with carbon cycling (and biogeochemistry) } \\
\text { (Norway) }\end{array}$ & Yes & Yes & Yes $^{\mathrm{b}}$ & Yes \\
\hline
\end{tabular}

${ }^{\text {a }}$ For historical and RCP8.5, we use run r6, because topsoil moisture is calculated incorrectly in the other runs (G. Strand 2016, personal communication).

${ }^{\mathrm{b}}$ Wind speed is not available, so we use the multimodel climatology (section 2a).

${ }^{\mathrm{c}}$ This model is in PMIP3 only. No RCP8.5 is available, so it is used for neither historical nor RCP8.5.

${ }^{\mathrm{d}}$ Unrelated to the models below with the same name, this model is based instead on an ancestor of MPI-ESM-LR.

${ }^{\mathrm{e}}$ For historical and RCP8.5, this is in fact available. So, the appropriate panel(s) of Fig. A1 include this model for completeness.

${ }^{\mathrm{f}}$ For preindustrial control, we use the p142 configuration for compatibility with the LGM run (see http://data.giss.nasa.gov/modelE/ar5/).

${ }^{\mathrm{g}}$ LGM latent heat flux [for the Scheff and Frierson (2015) method] is not available, so we estimate latent heat flux as $2.45 \times 10^{6} \mathrm{~J} \mathrm{~kg}^{-1}$ times $E$ for all experiments.

${ }^{\mathrm{h}}$ Near-surface thermodynamics and wind are output below rather than above the canopy (M. Watanabe 2013, personal communication), which is incompatible with Penman-Monteith.

${ }^{\mathrm{i}}$ This is not strictly available for RCP8.5. However, MPI-ESM-LR is available and used for RCP8.5 and historical. It is essentially identical (T. Mauritsen 2015, personal communication).

$\mathrm{j}$ Wind speed is given on a different grid than the other variables. See the appendix of Scheff and Frierson (2014).

${ }^{\mathrm{k}}$ The RCP8.5 average is taken only over 2070-98, because full-year 2099 output is not available.

${ }^{1}$ For historical and RCP8.5 we use run $\mathrm{r} 2$, because $\mathrm{r} 1$ is only partially available.

${ }^{\mathrm{m}}$ Evapotranspiration is not available, so we estimate it as latent heat flux divided by $2.45 \times 10^{6} \mathrm{~J} \mathrm{~kg}^{-1}$.

Results are only displayed where at least $2 / 3$ of the possible models had sufficient ice-free land.

For comparison and reference, all of this is also computed for the 2070-99 mean of the strong future warming experiment [representative concentration pathway 8.5 (RCP8.5)] minus the 1975-2004 mean of the historical experiment, for all available CMIP5 models (up to 43; listed in Table 1), using 1975-2004 as the PDSI reference period. This is done over all model grid cells that have at least $5 \%$ ice-free land in the historical period. Several of these models, including CCSM4, did not save surface wind speed (noted in Table 1), so 1975-2004 and 2070-99 multimodel wind speed climatology fields are substituted in these models, analogous to the 
CCSM4 procedure above. Exceptions to all of the above procedures are noted in Table 1.

\section{b. Vegetation change analysis}

\section{1) LGM VEGETATION}

For the LGM, the BIOME 6000 project (Prentice et al. 2000) has uniquely compiled a large fraction of the available pollen and plant macrofossil sites and used a common "biomization" statistical approach (Prentice et al. 1996) to classify the samples into biomes defined using combinations of plant functional types. The details and results of the implementation differed by region and are described by Jolly et al. (1998) and Elenga et al. (2000) for Africa; Kaplan et al. (2003) and Bigelow et al.

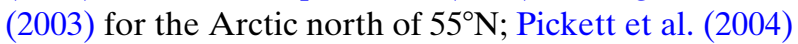
for Australasia, Southeast Asia, and the Pacific; Yu et al. $(1998,2000)$ and Harrison et al. (2001) for China and vicinity; Prentice et al. (1996), Peyron et al. (1998), and Elenga et al. (2000) for Europe south of $55^{\circ} \mathrm{N}$ and the Middle East; Takahara et al. (2000) for Japan; Marchant et al. (2009) for Latin America; Tarasov et al. (1998, 2000) for the former Soviet Union and Mongolia; Thompson and Anderson (2000) for the western United States; and Williams et al. (2000) for the eastern United States and southern Canada. Also, only Tarasov et al. (2000) and Thompson and Anderson (2000) analyzed macrofossils in addition to pollen; all others were pollen only. All of these studies found that their final methods reconstructed modern vegetation reasonably well from modern samples, especially over broad spatial scales. Thus, we use the BIOME 6000 results to describe known LGM vegetation, as do Prentice et al. (2011). Most of the samples likely date from $16000-20000{ }^{14} \mathrm{C}$ yr before present, which is $\sim 19000-23000$ calendar yr ago (e.g., Bigelow et al. 2003); age uncertainties are given in the above references. (In some of the later studies, samples were further restricted to $\sim 20000-22000$ calendar yr ago.)

Most of the BIOME 6000 results are downloadable online (http://www.bridge.bris.ac.uk/resources/Databases/ BIOMES_data/BIOME_v4_2.xls), with standardized biome names. However, those in Latin America (Marchant et al. 2009) postdate this table, and most of the Tarasov et al. (2000) sites in the former Soviet Union north of $55^{\circ} \mathrm{N}$ were not available to Bigelow et al. (2003) for reanalysis (N. Bigelow 2016, personal communication) and thus are also not in the table, so we added those by hand. In Marchant et al. (2009), the classifications and/or locations of some of the LGM samples differ between the paper's tables and figures; we use the tabular versions, which the paper preferred. Marchant et al. (2009) also reanalyzed two sites (Rano Aroui and Rano Raraku, Easter Island) from Pickett et al. (2004); we only use these later analyses. Finally, because Bigelow et al. (2003) improve on the earlier studies north of $55^{\circ} \mathrm{N}$ by splitting the "tundra" biome into several types with very different hydroclimatic associations, LGM sites classified as tundra by studies other than Bigelow et al. (2003), including several of the added Tarasov et al. (2000) sites, are not plotted in section 3.

All of the BIOME 6000 sites we consider are listed in Tables S1-S10 in the supplemental material. For sites where multiple LGM-era samples are in BIOME 6000 and the results conflict, we follow the choice in the region's BIOME 6000 reference paper [except in Australasia, where Pickett et al. (2004) did not choose favored results; see Table S3].

\section{2) Present natural Vegetation}

To characterize the LGM-preindustrial difference in vegetation near each site, it would be ideal to use nearcore-top pollen (or modern debris, for macrofossils) from each site, classified using the same method as the LGM sample. This would allow any reconstruction errors to cancel somewhat. However, a large majority of the paleo entries in BIOME 6000 do not include such information, as the modern samples were taken from separate locations. Also, many of the modern samples reflect anthropogenic (e.g., pasture and cleared forest) rather than potential or natural vegetation (S. Harrison 2015, personal communication).

Therefore, we instead derive the present potential vegetation from the literature, phrased in terms of the regional BIOME 6000 classification, if possible. For the former Soviet Union and Mongolia, Tarasov et al. (2000) directly include this information in their table of LGM sites. Most of the other studies include an areal map of this information (without the sites marked); we simply locate each site on this map. If a site is on a drowned continental shelf, we use the vegetation of the closest land. If a site is near a boundary between biomes or in a heterogeneous area (e.g., complex terrain), we consult the potential-vegetation description in that site's original reference when possible (or, if needed, other sources), and if it is a pollen site we also note the other nearby biomes. Occasionally individual sites are mentioned in the body text of the BIOME 6000 studies; this can also help resolve these cases. Pickett et al. (2004) do not include a vegetation map for the part of their study area outside Australia, and most of the eastern U.S. map in Williams et al. (2000) is covered up by the modern pollen symbols, so the textual strategies are used entirely in those areas. The Arctic map in Bigelow et al. (2003) shows potential vegetation only at the modern sites, but it has forest or one of the shrub tundras at all of them, so we assume all their LGM sites are also 
presently forest or one of the shrub tundras, which turns out to be sufficient (see below). Finally, Marchant et al. (2009) also include present vegetation in their site table for Latin America, but the entries often conflict with their vegetation map and/or body text, so the original references are consulted in these cases as well. In several of these cases, the site locations given in and used by Marchant et al. (2009) [and thus Prentice et al. (2011) and Harrison and Bartlein (2012)] turn out to be hundreds or even thousands of kilometers from the locations given in the original references (see footnotes $\mathrm{f}, \mathrm{e}, \mathrm{g}$, and a of Table S7), likely as a result of typographical errors by Marchant et al. (2009).

All of these present potential vegetation determinations, other nearby or alternate vegetation types, and their sources are given in Tables S1-S10. The lead author encourages any corrections or other guidance from individuals familiar with these sites. For a handful of sites, the present potential vegetation could not be determined; these are not plotted but are still listed.

\section{3) Ecological change}

With all this information, we attempt to classify each site as to whether the LGM vegetation, if found today at Holocene-like $\mathrm{CO}_{2}$ levels, would be associated with more, equally, or less water-limited conditions than the present natural (potential) vegetation-that is, whether the LGM was locally "browner" (drier looking) or "greener" (wetter looking) than the present. The BIOME 6000 studies cited above, and previous syntheses such as Prentice et al. (2011), verbally indicate that it was browner more often than greener, but this difference has never been precisely mapped or tallied across the landscape for comparison with model-variable responses.

Following the descriptions in the BIOME 6000 studies, we consider any change from 1) steppe or graminoid and forb tundra to forest, any of the shrub tundras, woodland, savanna, or xerophytic woods/scrub; 2) woodland or savanna to forest; 3 ) tropical deciduous/ dry forest to semievergreen/seasonal or evergreen/rain forest; 4) semievergreen/seasonal or sclerophyll to evergreen/rain forest; or 5) desert to any of these biomes as greening or wetter looking in the above sense and the reverse changes as browning or drier looking. Similarly, we consider a lack of biome change, or changes between rain forests, the various temperate and boreal forests, and/or shrub tundras, as "neutral." If an alternate possibility for the present potential vegetation would give a different result, the site is flagged as uncertain and plotted with a less prominent symbol (section 3c), or simply not plotted in extreme cases. [Changes to and from the rare, cold-determined cushion-forb tundra (Bigelow et al. 2003) and cool grassland (Marchant et al.
2009) biomes are also not plotted.] Because the various temperate and boreal forests and shrub tundra types are treated equally, present potential vegetation for the Arctic (Bigelow et al. 2003), Japan (Takahara et al. 2000), and much of the eastern United States (Williams et al. 2000) can be expressed at a simpler, lower level (Tables S2, S6, and S10).

The xerophytic woods/scrub biome has a more complex treatment. In Australia (Pickett et al. 2004, their Figs. 1-2), it clearly occupies more water-limited regions than the sclerophyll woodlands and forests, so changes from woodland or forest to this biome are considered browning, and vice versa. However, at the LGM African sites (Elenga et al. 2000) it often represents alpine heath/ ericaceous vegetation found above the treeline (Taylor 1990; Gasse and Van Campo 1998), which may be more temperature limited, so a change from forest or woodland to this biome is still labeled browning [following the drying interpretations in Elenga et al. (2000) and Prentice et al. (2000)] but is flagged as uncertain, as above. Changes from forest or woodland to the cool grass shrubland biome in Latin America are handled the same way, since this biome also includes high-altitude wet moorlands (Marchant et al. 2009) in addition to dry grasslands. Also, the warm-temperate mixed forest biome in Latin America represents a relatively dry pineoak forest, so it is considered neutral vis-à-vis tropical semievergreen forest but drier looking than rain forest, following Fig. 5 of Marchant et al. (2009) [but the cooltemperate mixed and rain forests are kept together, on the advice of R. Marchant (2016, personal communication)]. Again, the lead author encourages any additional guidance from individuals familiar with these regions. The results of this analysis are given in Tables S1-S10.

\section{Results}

\section{a. Compilation and review of model responses to future warming and $\mathrm{CO}_{2}$}

Figure 1 reproduces the CMIP5 warming-driven ecohydrologic projections discussed in section 1 , for comparison to the LGM results in section $3 b$ and also to put all of these responses together in a single framework. All plots are multimodel median annual-mean differences between 2070-2099 in the strong-warming RCP8.5 scenario and 1975-2004 in the historical scenario, stippled where at least $80 \%$ of the models agree on the sign of the difference. Figure 1 only uses those models that simulated the LGM but Fig. A1 in the appendix shows that the results using the full CMIP5 suite of models are essentially identical.

Figure 1a shows the precipitation responses. The changes are more robust than implied by the more 
a) $P$ change $\left(\mathrm{mm}\right.$ day $\left.^{-1}\right)$

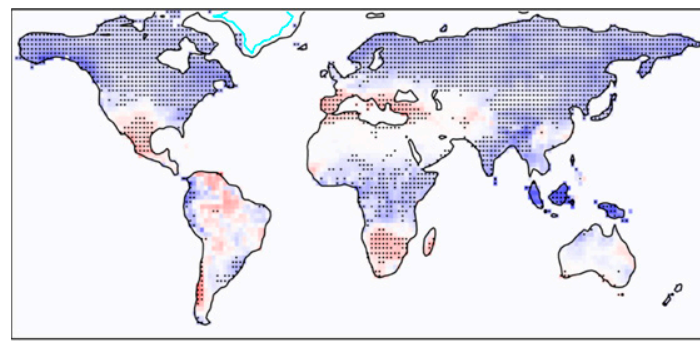

c) (P/PET) change

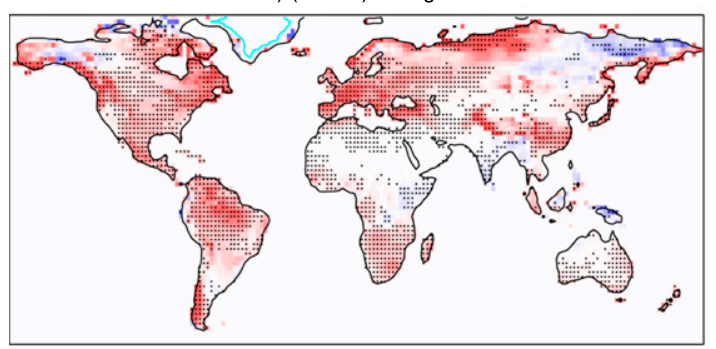

e) Topsoil moisture change $\left(\mathrm{m}^{3} \mathrm{~m}^{-3}\right)$

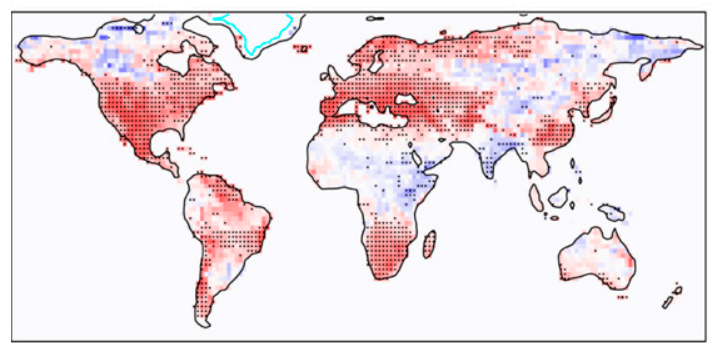

g) P-E change (mm day $\left.{ }^{-1}\right)$
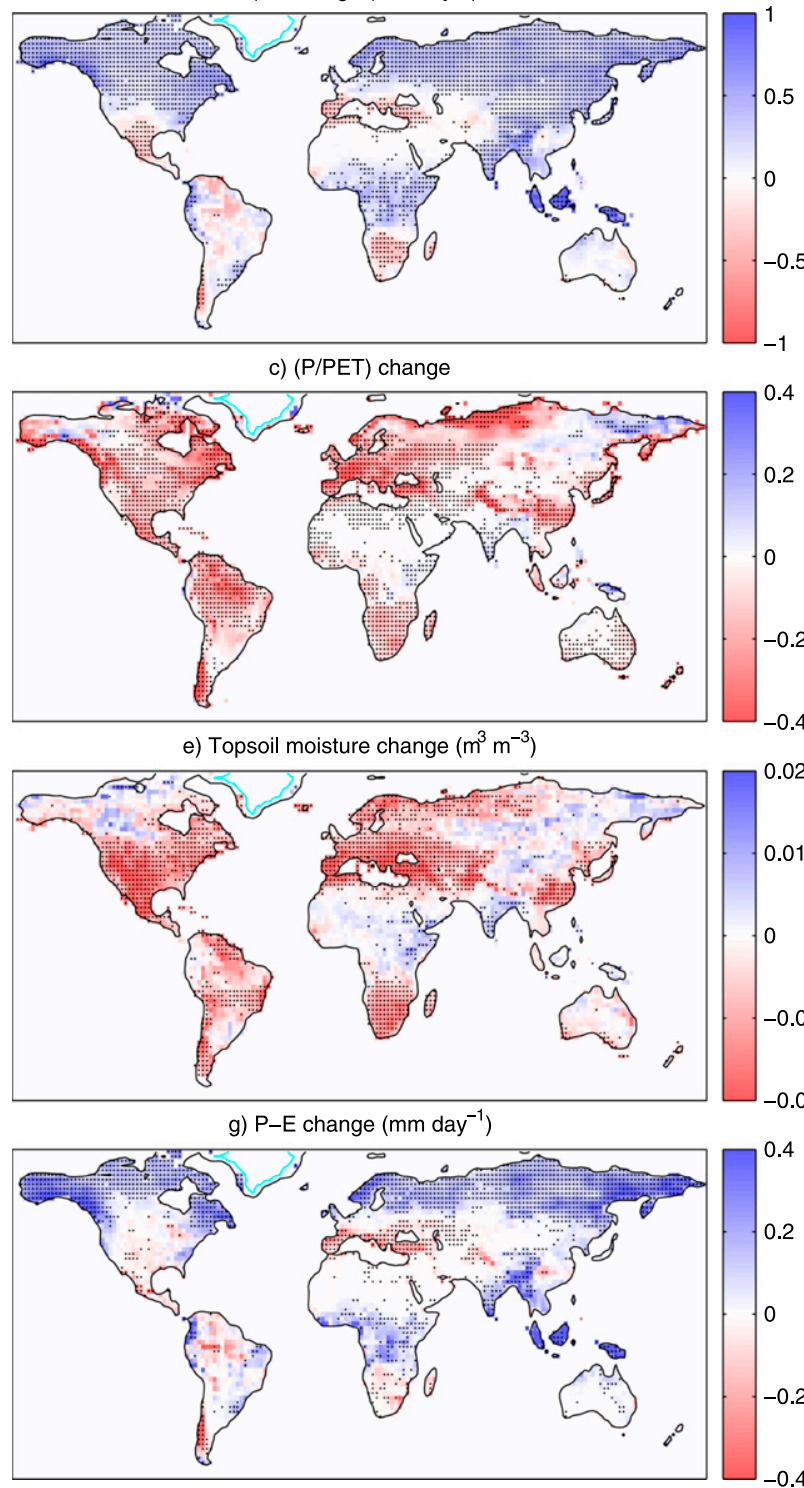

b) PET change (\%)
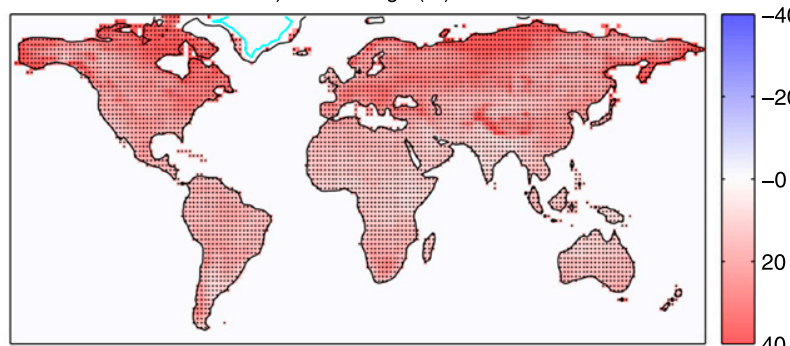

d) PDSI change
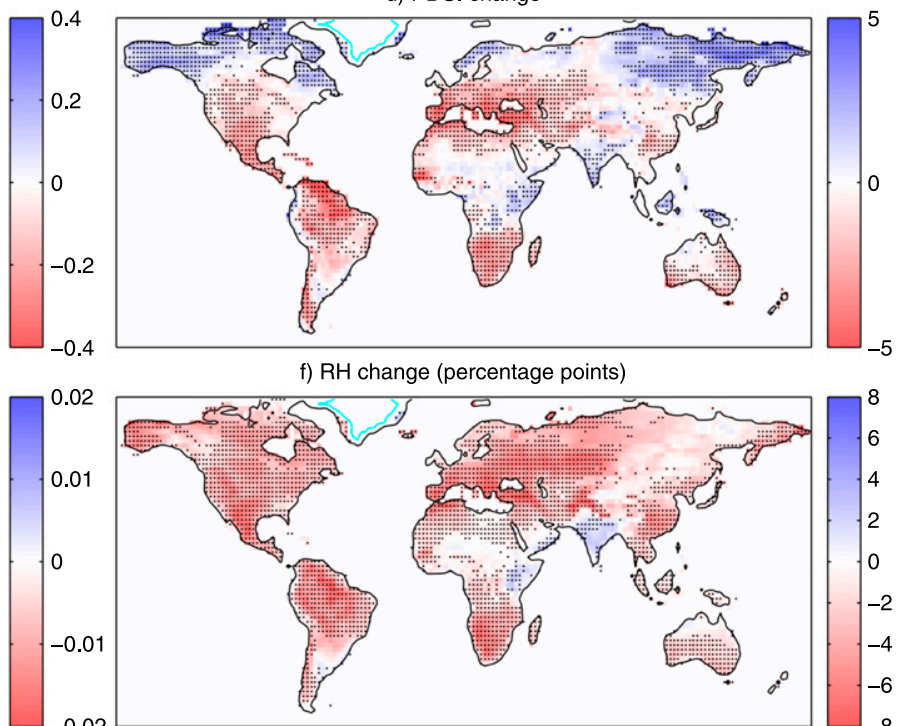

f) $\mathrm{RH}$ change (percentage points)

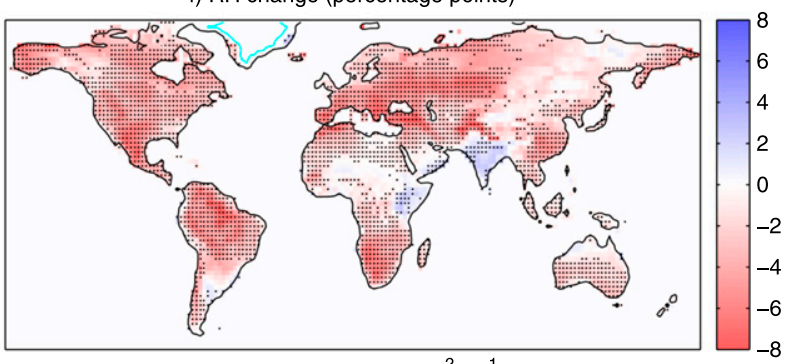

h) NPP change $\left(\mathrm{kg} \mathrm{C} \mathrm{m}^{-2} \mathrm{yr}^{-1}\right)$
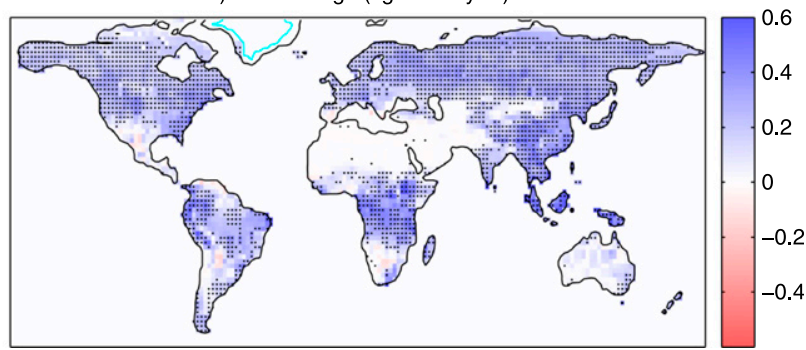

FIG. 1. Multimodel median 2070-99 minus 1975-2004 changes in annual-mean (a) $P$, (b) PET, (c) ratio of annual $P$ to annual PET, (d) PDSI, (e) topsoil $\theta$, (f) near-surface RH, (g) $P-E$ ( $\approx$ runoff production), and (h) NPP, taken over all CMIP5 models that simulated the LGM and for which these were available (listed above the blank row in Table 1). Stippling indicates that at least $80 \%$ of the models agree on the sign of the change. The 2070-99 output is from the strong warming experiment (RCP8.5) and the 1975-2004 output is from the historical experiment. Figure A1 shows that the results are nearly identical when the full suite of models is used.

qualitative analysis of Scheff and Frierson (2015), with very consistent increases poleward of about $50^{\circ} \mathrm{N}$ and robust regions of increase and decrease in many parts of the low to midlatitudes. As stated in much of the literature cited in section 1 , the responses outside of the high latitudes are dominated by regional signals and are not particularly zonal: the tropics, subtropics and midlatitudes all have areas of increasing and decreasing $P$, though declines are most concentrated in the subtropics.
Penman-Monteith PET (evaporative demand; Fig. 1b) robustly increases across all land by low double-digit percentages, which increase with latitude (e.g., Feng and $\mathrm{Fu}$ 2013; Scheff and Frierson 2014). Thus, in Fig. 1c, strong declines (drying) dominate the dimensionless aridity index P/PET (e.g., Middleton and Thomas 1997), with almost no areas of robust wetting. Figure 1c looks very similar to the equivalent in Feng and Fu (2013) and related literature. Figure 1d in turn shows that the response of the much more complex Palmer drought severity index is quite similar to 
this simple $P /$ PET response, especially outside the higher latitudes. This is sensible given that PDSI is primarily a function of the same two variables ( $P$ and PenmanMonteith PET).

Figure 1e then confirms that the response of topsoil moisture is very well predicted by the P/PET and PDSI responses, as first noted by Dai (2013). This response robustly extends down to $300 \mathrm{~mm}$ and is still detectable down to $1000 \mathrm{~mm}$ (not shown). Figure $1 \mathrm{f}$ shows the same for surface air relative humidity. As noted by Sherwood and $\mathrm{Fu}$ (2014), the similarity with $P /$ PET is remarkable. Again, the appendix shows that all of this holds in the full CMIP5 suite as well.

However, Fig. 1g strongly confirms the results of Roderick et al. (2014, 2015), Swann et al. (2016), and Milly and Dunne (2016) that the P/PET and PDSI metrics are not good predictors of the modeled response of $P-E$ (i.e., total runoff production). There is no sense of global or widespread decline of $P-E$ : instead, the regions of robust change are much more localized than for the other variables (including $P$ ), and the changes are consistently positive at high northern latitudes and mixed at other latitudes, as with $P$. (When only the models used in Figs. 1c-f are used to make this plot, it remains nearly identical.) However, contrary to some of the suggestions in the above studies, the $P-E$ response does not just imitate the $P$ response: $E$ change is quite regionally important. For example, very large areas of the northern midlatitudes and tropical Africa are projected to see robustly increasing $P$, but weak, nonrobust change in $P-E$. Similarly, the robust declines in $P$ in Mexico and southern Africa are much less robust in $P-E$.

In addition, Fig. $1 \mathrm{~h}$ shows that net photosynthesis is projected to increase almost everywhere-even where the other quantities robustly decline and even in much of the semiarid subtropics where water is limiting [Donohue et al. (2013) explain why such environments are actually ideal for $\mathrm{CO}_{2}$ fertilization]. Thus, neither of the two main ultimate motives for considering climatic drought and wetness-namely, runoff and vegetation production-respond to modeled warming and $\mathrm{CO}_{2}$ increase in a similar manner to the climatic wetness indices or to each other. In short, Fig. 1 makes it quite clear that under climate change, statements about local land drying and wetting are highly dependent on the quantity of interest, at least in GCMs.

\section{b. Model responses at the LGM}

Figure 2 maps the same quantities and models as Fig. 1, but for LGM minus preindustrial control. For precipitation, Fig. 2a is fairly antianalogous to Fig. 1a, with regions of simulated decrease at the LGM corresponding to regions of projected future increase, and vice versa. Thus, $P$ decreases dominate at higher latitudes and on eastern sides of midlatitude continents, with increases concentrated in parts of the subtropics and western midlatitudes. The analogy is not perfect: for example, in the Mediterranean $P$ only robustly increases in Iberia, even though nearly the whole basin sees robust decreases in the future projections. In North America, the increases are concentrated in the western United States rather than northern Mexico and its vicinity, and in northern South America there are robust decreases even though the future projections are varied and nonrobust. However, overall the anticorrespondence is strong, both in spatial pattern and in overall balance of trends.

Similarly, Fig. 2b shows that annual-mean PET robustly decreases in the simulated LGM by $\approx 10 \%-40 \%$ over nearly all land; in most places this decline occurs in every model (not shown). When each PenmanMonteith PET input is changed individually as in Scheff and Frierson (2014), it is found that the cooling itself explains most of the PET decline, with RH changes (of both signs) also locally important. The percentage declines are stronger at mid- to high latitudes than in the tropics. All of this is again opposite to the future simulations from Fig. 1b and Scheff and Frierson (2014). However, important exceptions are found in the high latitudes of each hemisphere in Fig. 2b (northern Russia, most of Alaska, and eastern Patagonia), where the PET decreases are not robust and even become increases in a few coastal grid cells. This is mostly because of strong warm-season RH declines in CNRM-CM5 and MRI-CGCM3 (northern Russia), CNRM-CM5 and MPI-ESM-P (Alaska), and in a number of models (Patagonia), which prevail over the cooling to increase PET. In CNRM-CM5 in northern Russia, warm-season warming (despite the strong radiative forcing for cooling) also contributes. A detailed analysis is beyond the scope of this study, but these are all regions where the LGM coastline was much farther out to sea than it is today (black outlines in Fig. 2), so one could posit that the increased continentality of the climate at the LGM is responsible. In northern Russia, the rain-shadow effect of the Fennoscandian ice sheet (visible in Fig. 2a, and particularly strong in CNRM-CM5 and MRI-CGCM3) may also contribute.

In any case, though, Figs. $2 \mathrm{c}$ and $2 \mathrm{~d}$ show that, except for these high-latitude regions, the modeled PET declines are indeed sufficient for widespread robust $P / P E T$ and PDSI increases at the LGM that again strongly resemble each other. These are not quite as dominant as the decreases in the future simulations (Figs. 1c,d) but are still clearly more common than local decreases, outside the high latitudes. In fact, the six models for 
a) $P$ change $\left(\mathrm{mm}\right.$ day $\left.^{-1}\right)$
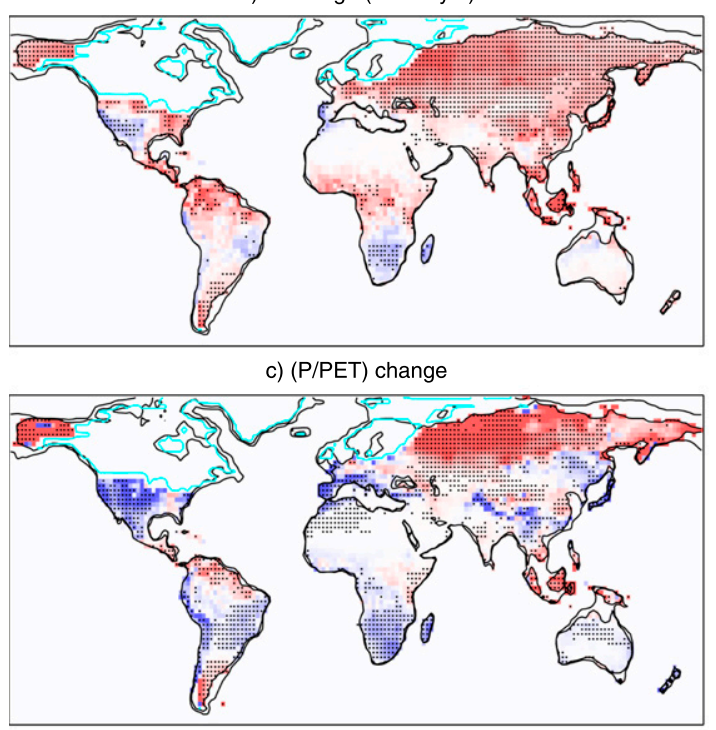

e) Topsoil moisture change $\left(\mathrm{m}^{3} \mathrm{~m}^{-3}\right)$

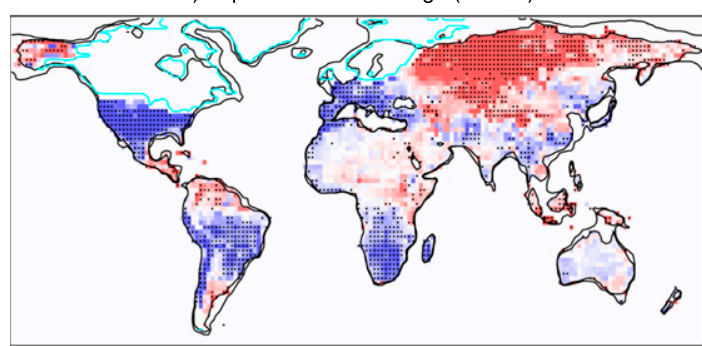

g) P-E change $\left(\mathrm{mm}\right.$ day $\left.^{-1}\right)$

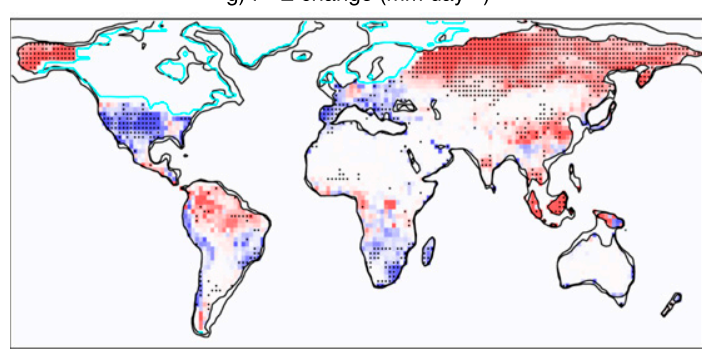

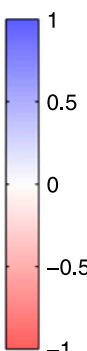
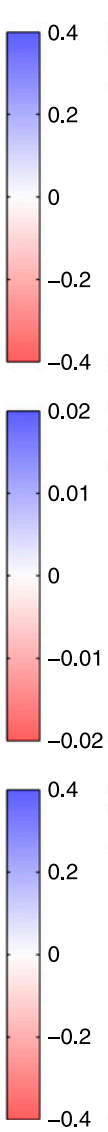

b) PET change (\%)

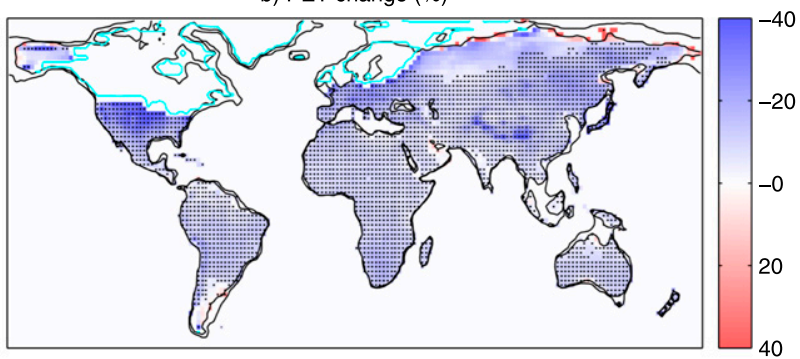

d) PDSI change

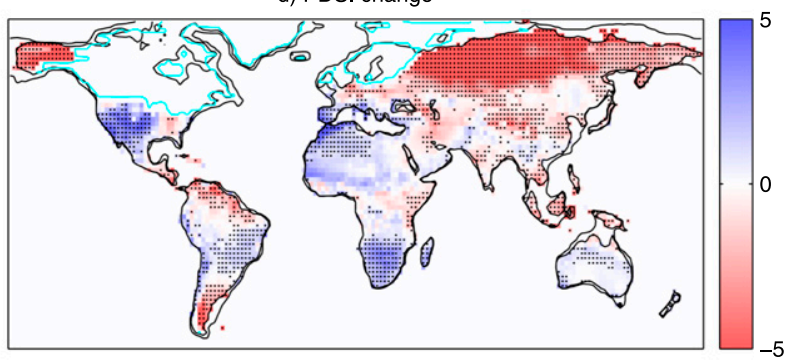

f) $\mathrm{RH}$ change (percentage points

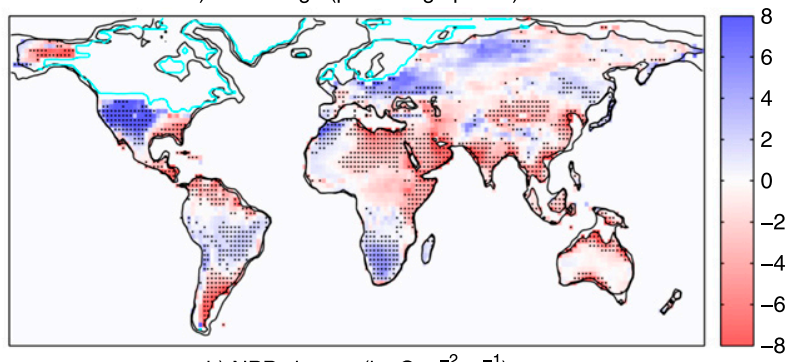

h) NPP change $\left(\mathrm{kg} \mathrm{C} \mathrm{m}^{-2} \mathrm{yr}^{-1}\right)$

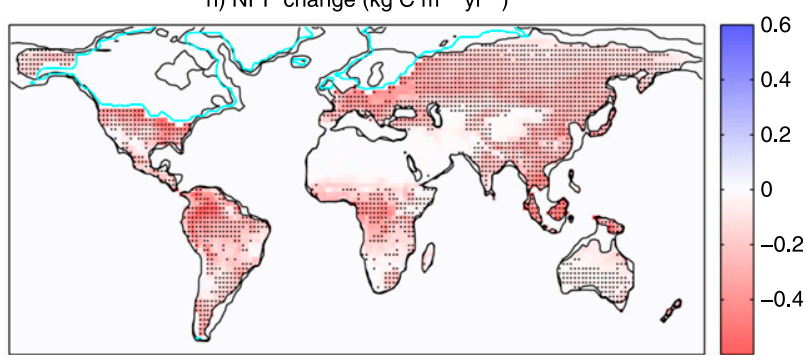

FIG. 2. As in Fig. 1, but for LGM minus preindustrial.

which PET and PDSI could be computed (Table 1), and which are used to make these figures, have more extensive median $P$ declines than the full nine-model ensemble from Fig. 2a (not shown). So the P/PET and PDSI increases would presumably be even more widespread if the full ensemble could be used.

In turn, Fig. 2e confirms that the modeled topsoil wetness (i.e., $\theta$ ) also robustly increases at the LGM in much of the low to midlatitudes, closely resembling the $P /$ PET and PDSI increases despite the slightly different sets of models used (Table 1). (The resemblance is similar or even a bit better using only the five models in common.) Once again, this is strongly (anti)analogous to the future simulations (Figs. 1c-e). Also closely following
P/PET and PDSI, $\theta$ robustly decreases in much of Russia, Alaska, and Patagonia at high latitudes (see above).

On the other hand, Fig. $2 \mathrm{f}$ shows that, in contrast to the widespread $\mathrm{RH}$ decrease in response to future warming, the annual-mean near-surface $\mathrm{RH}$ change at the LGM is highly variable and does not resemble the changes in topsoil moisture, P/PET, and PDSI. It actually shows widespread drying in the low to midlatitudes, and the expected robust wetting is mostly limited to parts of the Americas and Africa. The same models are used for RH as for P/PET and PDSI (Table 1), so model selection cannot account for these differences. This suggests that the decline of land $\mathrm{RH}$ with increasing global temperature analyzed by, for example, Berg et al. 
(2016) and Byrne and O'Gorman (2016) is not robust for colder base climates.

Figure $2 \mathrm{~g}$ shows the LGM response of modeled $P-E$. The antianalogy with the future response (Fig. 1g) is good but far from perfect-North America and northern South America particularly stand out as locations where the LGM and future responses are not opposite. As a result, the contrast between the $P-E$ and other variables is not as strong as it was for the future projections. However, the $P-E$ increases are clearly still not as widespread or consistent as the topsoil moisture, PDSI, or P/PET increases in Fig. 2. The (anti)correspondence between simulated past and future is stronger for photosynthesis: Fig. 2h shows that the available GCMs simulate large, robust declines in net primary productivity at the LGM (cf. Fig. 1h). They do so everywhere except for the extreme deserts, where $\mathrm{NPP} \approx 0$, and a few other subtropical regions. Again, the photosynthesis responses seem to be largely unrelated to those of soil moisture and $P / \mathrm{PET}$. Presumably, this is because direct effects of the low glacial $\mathrm{CO}_{2}$ dominate (analogous to the high $\mathrm{CO}_{2}$ in the future simulations), though the low temperature could also be important. Without LGM GCM experiments that turn the $\mathrm{CO}_{2}-$ plant pathway on and off as in Arora et al. (2013), this cannot be known for certain.

\section{c. Observed ecological change}

One might now wonder which of these contrasting model metrics most resemble(s) the actual vegetation cover changes that occurred at the LGM relative to the present. After all, the photosynthesis submodels in most of the CMIP5 land models are relatively crude: they do not even allow the vegetation type to change, nor do they account for nutrient constraints (De Kauwe et al. 2013), plant mortality due to hydraulic failure (Anderegg et al. 2012), or other factors observed to complicate $\mathrm{CO}_{2}$ fertilization. Meanwhile, $P, P / \mathrm{PET}$, and PDSI are routinely used to quantify ecosystem water limitation in the present and are often assumed by their proponents to have strong ecological relevance under future climate change. Which (if any) do the BIOME 6000-inferred greenness changes look like?

Figure $3 \mathrm{a}$ first plots the vegetation change categories from Tables S1-S10 on top of the model PDSI changes from Fig. 2d, which are very similar to the P/PET and topsoil moisture changes as shown above. Green circles denote likely leafier or wetter-looking natural vegetation at the LGM relative to preindustrial [e.g., woodland where there is modern desert (e.g., woodland where there is modern desert), notated "W" in Tables S1-S10; brown circles denote likely sparser or drier-looking vegetation (e.g., steppe where there is modern forest), notated "D"; and gray circles denote the same vegetation, or vegetation without a strong apparent-moisture contrast (e.g., warmtemperate rain forest where there is modern tropical rain forest), notated "N." Circles are open where this determination was uncertain (lowercase letters in the tables). See section $2 b$ (3) for more details. (Where symbols overlap, filled circles are always plotted on top of open circles, and within each, green are plotted on top of brown on top of gray.)

It is immediately apparent that, while the brown (and gray) circles are ubiquitous, observed greening at the LGM relative to the present is rare globally and confined mostly to the western to central United States. The patterns of symbols in Fig. 3a broadly agree with the textual descriptions given in Prentice et al. (2011) and the BIOME 6000 studies, but the extent of the drierlooking vegetation can be seen much more precisely in this view. There are a total of 144 drier-looking sites, of which 116 are filled, but just 17 wetter-looking sites, of which 9 are filled (out of 302 BIOME 6000 sites evaluated). In many parts of Africa, southern Europe, western North America, central South America, and southeastern Australia where the PDSI projects glacial wetness or little change, the LGM vegetation would be associated with more water-stressed conditions if found today. Thus, the model projections of PDSI, P/PET, and topsoil moisture are not particularly good guides to LGM ecological changes.

In contrast, Fig. 3b shows much better agreement between the observed LGM vegetation changes and the simulated photosynthesis (NPP) changes, with widespread browning over the globe in each, again analogous to the Prentice et al. (2011) result. The modeled photosynthesis decline is actually too ubiquitous-there is no robust greening at all—but the (modest) observed greening is still disproportionately found in areas where the modeled browning is nonrobust or weak. In fact, all but one of the sites with a clear greening interpretation (filled green circles) are in such areas: specifically, in parts of the southwestern United States and southwestern Africa.

The widespread gray circles in areas with strong projected changes do not pose as much of a problem (both here and in Fig. 3a). This is because $\mathrm{CO}_{2}$ and climate changes will only cause a detectable greenness change in our method if the vegetation happens to be close enough to one of the thresholds defined in section $2 b(3)$ for the regional atmospheric changes to pull it over that threshold. For example, a temperate forest that is very well watered might still remain a forest at glacial $\mathrm{CO}_{2}$ or lower PDSI (and a desert will remain a desert).

In any case, given the slight overestimation of glacial browning extent by the model NPP, we also consider whether plain precipitation might be a useful guide to observed vegetation change, again contrary to the 
a) PDSI change with obs vegetation change

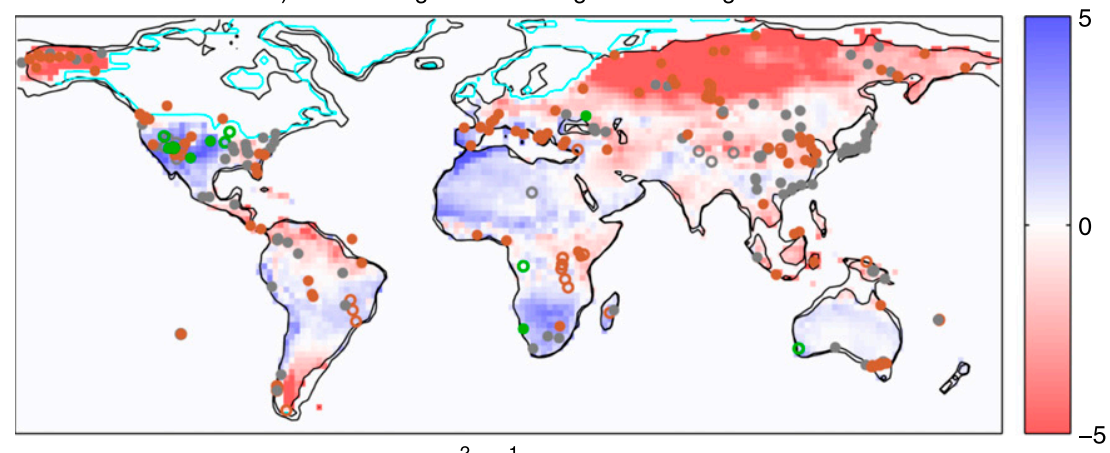

b) NPP change $\left(\mathrm{kg} \mathrm{C} \mathrm{m}^{-2} \mathrm{yr}^{-1}\right)$ with obs vegetation change
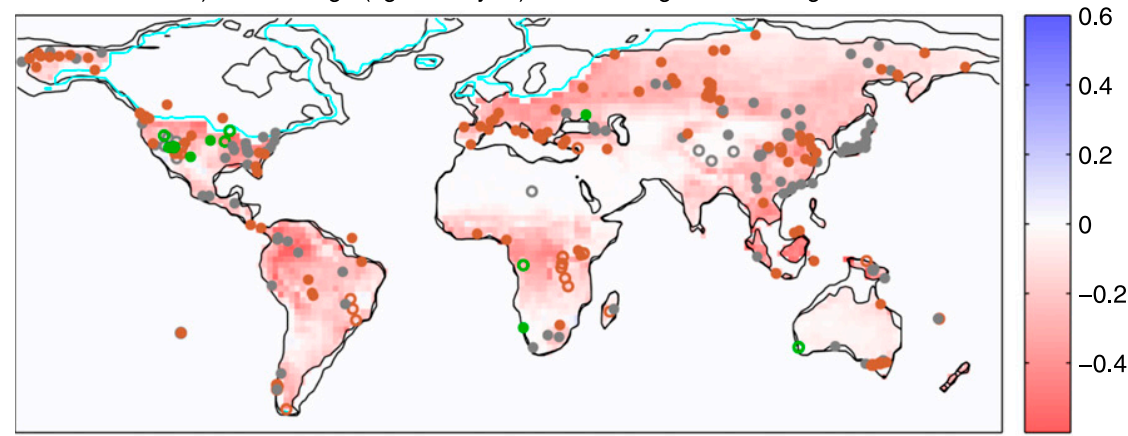

c) $\mathrm{P}$ change $\left(\mathrm{mm} \mathrm{day}^{-1}\right)$ with obs vegetation change
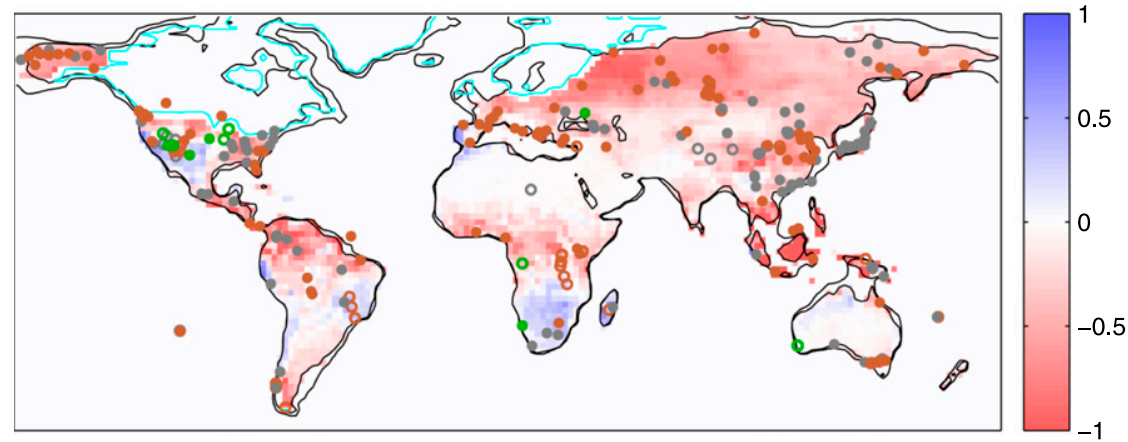

d) $P-E$ change $\left(\mathrm{mm} \mathrm{day}^{-1}\right)$ with obs vegetation change

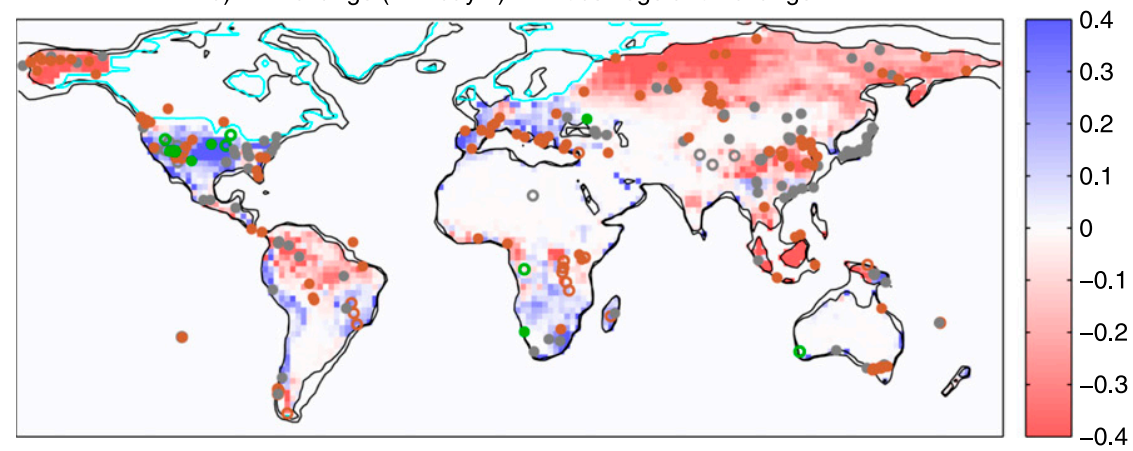

FIG. 3. Multimodel median LGM minus preindustrial changes in annual-mean (a) PDSI, (b) NPP, (c) $P$, and (d) $P-E$, as in Fig. 2. Brown (green) circles are overlaid where the BIOME 6000 LGM vegetation, if found today, would be associated with more (less) waterlimited conditions than the present potential vegetation, and correspond to $\mathrm{D}(\mathrm{W})$ in Tables $\mathrm{S} 1-\mathrm{S} 10$. See section $2 \mathrm{~b}$ (3) for details. Gray circles (N in Tables S1-S10) are plotted where the LGM vegetation is the same as the present or would not clearly suggest a water-stress change if found at present, and open circles (lowercase letters in Tables S1-S10) denote uncertain determinations. The stippling from Fig. 2 is omitted, for visual clarity. 
implicit assumptions of studies like Scheff and Frierson (2015) and Cook et al. (2014). Figure 3c shows that this also works reasonably well: there is disagreement in Iberia, southeastern Africa, and probably the Brazilian highlands, where LGM vegetation browns despite modeled increases in $P$, but also somewhat more agreement with the greening sites in the western United States and southwestern Africa. Overall, the true global vegetation response appears to have been somewhere between the implications of model $P$ and NPP. Again, though, it does not seem to have qualitatively resembled the modeled changes in topsoil moisture, P/PET, PDSI, or even $P-E$ (Fig. 3d).

Some of this disagreement (Figs. 3a,d) might alternatively be explained by wet biases in the LGM responses of $P$ and PET and thus of PDSI, $P-E$, and so on. However, cursory comparison of the model $P-E$ responses (Fig. $2 \mathrm{~g}$ ) with the LGM results from a recent version of the Global Lake Status Database [Fig. 14.8e of Harrison and Bartlein (2012)] suggests that the former are at least qualitatively accurate over large areas: LGM closedbasin lake levels (and thus $P-E$ in the surrounding watersheds) were apparently much higher than present in the western United States, the Andes around $30^{\circ}-40^{\circ} \mathrm{S}$, the eastern Mediterranean, the northwest rim of the Sahara, southern Africa, and inner Southeast Asia and lower than present in southern Mexico, Colombia, eastcentral Africa, and the Mt. Cameroon area, all in agreement with the simulations. They were also high throughout western China, suggesting a (regional) dry bias in model LGM $P-E$, rather than a wet bias. Many of these regional LGM lake highstands were also highlighted by Broecker (2010). Planned future work will formalize this comparison, but the reasonable agreement of both the model $P-E$ to the hydrological changes and the model NPP to the ecological changes (but not to each other) strongly suggests that the fully coupled models are qualitatively correct in their simulation of the terrestrial system response at the LGM.

\section{Discussion}

\section{a. Implications}

What, then, are the consequences of accepting this model-inspired narrative? For paleoclimatologists, the most immediate is that the mid- to low-latitude LGM (and likely other Pleistocene glacial stages) may have been broadly dry in terms of terrestrial precipitation (Fig. 2a), but not in terms of hydrology ( $P-E$; Fig. 2g) or soil moisture (Fig. 2e), likely as a result of the lower evaporative demand (PET; Fig. 2b) from the colder temperatures. The global declines in vegetation greenness and $\mathrm{C}_{3}$ plant cover at the LGM (e.g., Fig. 3b), so often taken as evidence for terrestrial water scarcity, instead seem to be driven by the low glacial $\mathrm{CO}_{2}$ (and perhaps cold temperatures), as argued by, for example, Gerhart and Ward (2010) and Prentice et al. (2011). Thus, a local finding of proxies for more open, sparse, or $\mathrm{C}_{4}$-dominated vegetation during a glacial than during an interglacial should not generally be taken as evidence that local rivers, lakes, aquifers, or soils were drier during the glacial. Instead, actual hydrologic (nonplant) proxies are required to show this. Figure $3 \mathrm{~d}$ confirms that many LGM browning sites, most of which were originally interpreted as drying, are located where modeled $P-E$ (and topsoil moisture) were at least as large as at present throughout Europe, the Americas, and parts of Africa and Australia, including waterlimited subtropical areas. In this view, the apparent conflict between dry vegetation and high lake levels in the LGM eastern Mediterranean and other areas is no conflict at all, as also argued on a purely climatic basis by Prentice et al. (1992).

For investigators of future hydroclimate change, the key conclusion is that the last time Earth experienced global warming in which $\mathrm{CO}_{2}$ and other greenhouse gases were major factors (the change from the LGM forward to the preindustrial), the model NPP (and, to a large extent, precipitation) fields proved to be reasonable predictors of the low- to midlatitude vegetation response (Figs. 3b,c), whereas the P/PET, PDSI, topsoil moisture, and $P-E$ fields did not (Figs. 3a,d). Similarly, the model $P-E$ field did reasonably well at projecting the lake-inflow responses as just discussed, consistent with $P-E$ being the most relevant climate quantity for stream and aquifer flow. Since future direct projections of $P-E$ and total runoff are much more positive than future projections of $P / P E T$, PDSI, or PET-driven downscaled runoff (Fig. 1; Roderick et al. 2015; Milly and Dunne 2016), they should not be ignored when thinking about future stream and groundwater change.

\section{b. Counterarguments and responses}

One might argue that the much shorter time scale of the twenty-first century compared to the entire last deglaciation and Holocene will lead to a reduced greening response compared to Fig. 1h, particularly where nutrient supply is limiting today. More generally, the future greening response in models is not well constrained from historical observations. However, as Roderick et al. (2015) clearly explain, any model overestimation of greening would imply that leaf-level stomatal closure and $E$ decrease because of the direct physiological effects of the increased $\mathrm{CO}_{2}$ (e.g., Sellers et al. 1996) will not be compensated as strongly by leaf area increase, so 
a) $P$ change $\left(m m\right.$ day $\left.^{-1}\right)$

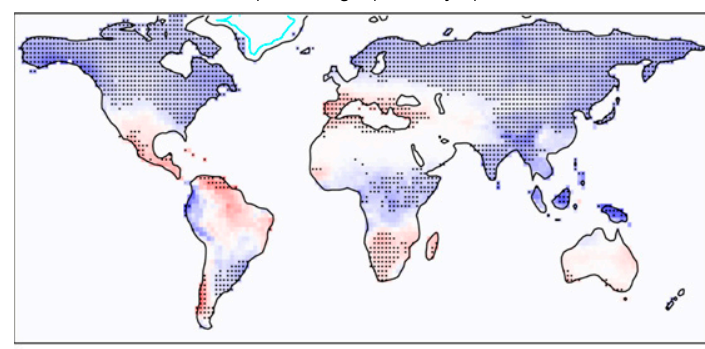

c) (P/PET) change

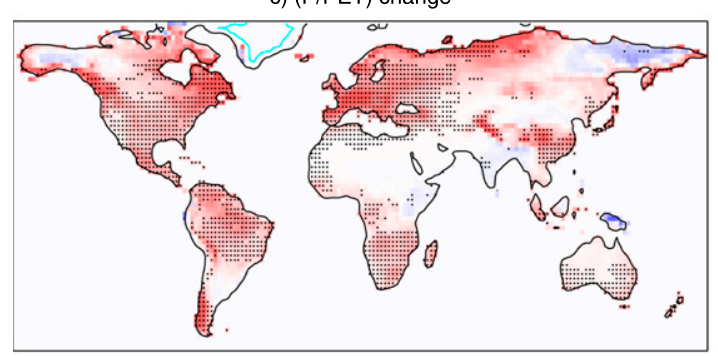

e) Topsoil moisture change $\left(\mathrm{m}^{3} \mathrm{~m}^{-3}\right)$

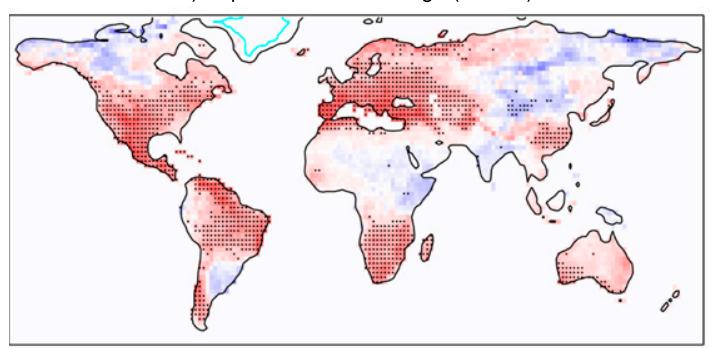

g) P-E change ( $\left.\mathrm{mm} \mathrm{day}^{-1}\right)$

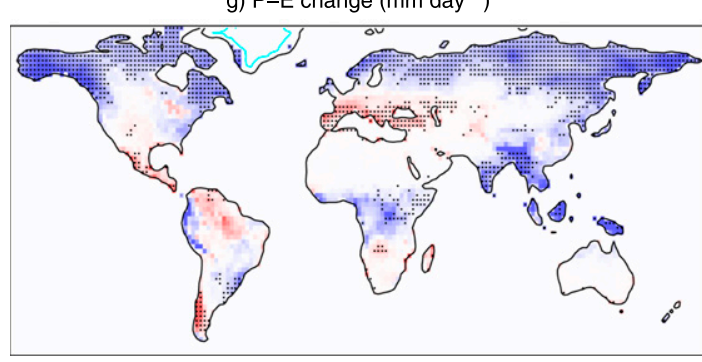

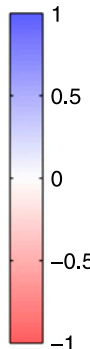
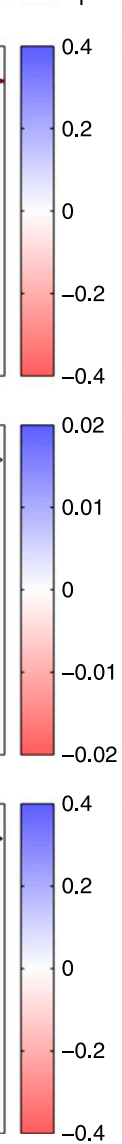

b) PET change (\%)

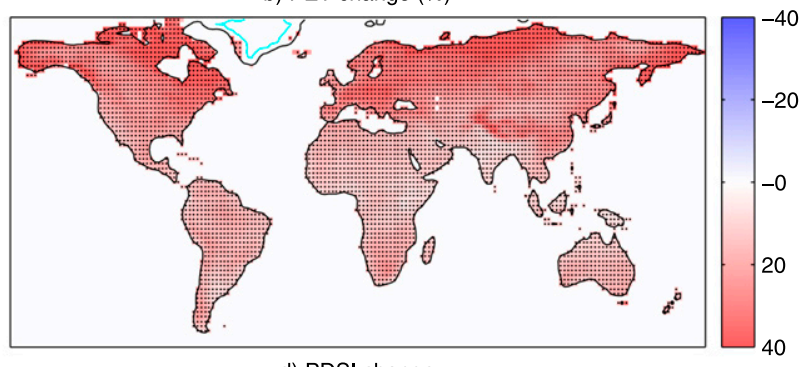

d) PDSI change

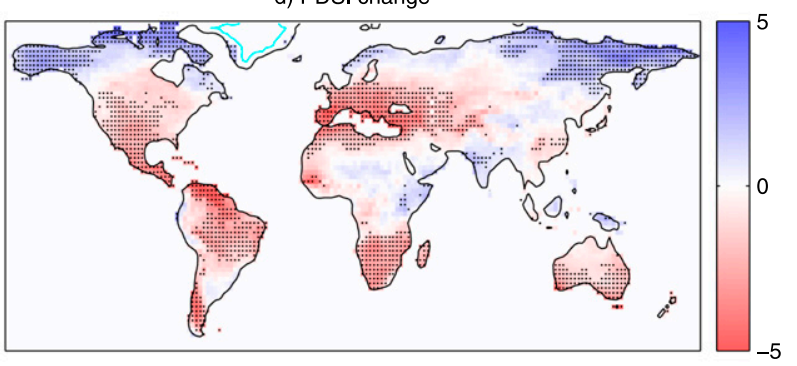

f) $\mathrm{RH}$ change (percentage points)

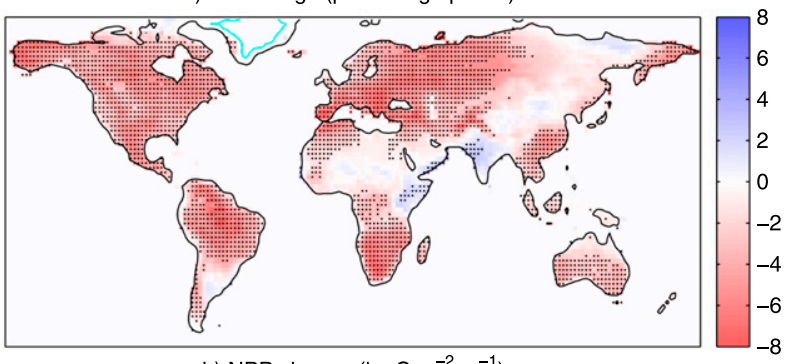

h) NPP change $\left(\mathrm{kg} \mathrm{C} \mathrm{m}^{-2} \mathrm{yr}^{-1}\right)$

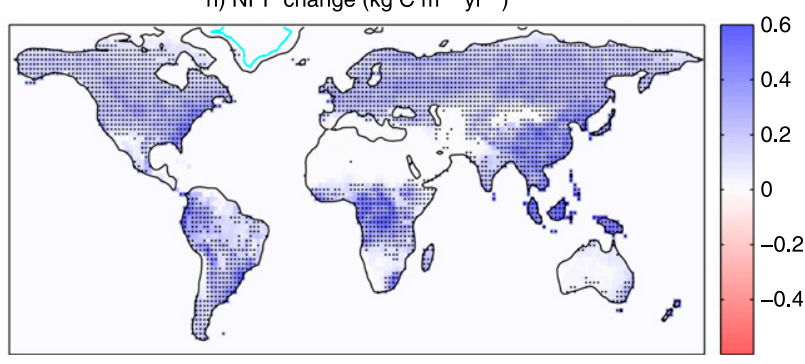

FIG. A1. As in Fig. 1, but for all models in Table 1, not just those that simulated the LGM.

runoff production will decrease even less (or increase even more) compared to Fig. 1g.

One might also object that the globally widespread increase in dust deposition at the LGM compared to the present (Harrison and Bartlein 2012; Muhs 2013) calls the idea of wet LGM topsoils and varied LGM $P-E$ into question. It is quite often because of this dustiness that glacials are called dry (e.g., Petit et al. 1999). However, most of the key proposed mechanisms for this increase compiled by Muhs (2013), such as vegetation cover reduction, longer aerial dust lifetimes due to lower $P$, continental shelf exposure in dry regions, proliferation of glaciogenic dust sources, and increased extreme wind gusts, are entirely consistent with the simulations [see also
McGee et al. (2010)]. The vegetation cover reduction is strongly confirmed here, and generally lower $P$ is also suggested, but simultaneous with wetter topsoils. Actually, in central Asia and eastern Patagonia, two of the key dust source regions, the GCMs do project drier LGM topsoils (unlike in much of the low to midlatitudes), again consistent with the dust record. In short, the global LGM dust record does not conflict with our results and does not imply that global land surfaces were generally drier. Indeed, Hopcroft et al. (2015) and Albani et al. (2016) show that CMIP5 GCMs successfully simulate the high glacial dust deposition despite the lack of low- to midlatitude soil and lake drying, and Hopcroft et al. (2015) attribute this mainly to the reduced vegetation cover. 
Finally, this work also implies that the apparent pastfuture tension discussed in section 1, named the "aridity paradox" by Roderick et al. (2015), is not a paradox but just a lack of understanding that different land properties related to wetness can behave quite differently under identical greenhouse climate change. This largely agrees with the solution offered by Roderick et al. (2015); in most respects, the LGM is an eco-hydrologic (anti)analog for the expected future, not a counterexample. In other words, the response to past warming (from LGM to preindustrial) resembles the response to future warming. However, it is still very interesting that the $P-E$ projections are considerably closer to $P / \mathrm{PET}$ or PDSI for the LGM than for the future, as noted in section $3 b$. Furthermore, the lithologic evidence from past hot greenhouses (Boucot et al. 2013) still suggests very wet soil conditions outside of the subtropical deserts, contrary to the robustly simulated future soil moisture declines discussed in sections 1 and 3 a. Is there still room for more modest and focused aridity paradox(es)? The lead author intends to explore such questions in future work.

\section{Conclusions}

A new understanding is emerging from comprehensive climate models that whether greenhouse warming will cause local wetting or local drying on land strongly depends on just what is meant by "wetting" and "drying." In this study, we buttress this idea by showing that the models also respond this way at the Last Glacial Maximum ( $\sim 21000 \mathrm{yr}$ ago) and that the paleoecologic and paleohydrologic evidence from that time is most consistent with this understanding. In particular, the low- to midlatitude LGM relative to the present seems to have been largely wetter in the sense of topsoil moisture and two common climate wetness indices, variously wetter and drier in the sense of runoff, but largely drier in the sense of precipitation, and nearubiquitously browner in terms of vegetation. Thus, work that infers river/aquifer or soil dryness during glacials from plant-based proxies, or that assumes ecohydrologic consequences from index-based projections of future drying, should be interpreted with caution.

Acknowledgments. J.S. thanks B. Cook, P. Greve, S. Harrison, P. Polissar, and M. Roderick for useful and invigorating discussions and T. Mauritsen for providing the MPI-ESM-P/MPI-ESM-LR surface dewpoint output. The authors also acknowledge the World Climate Research Programme's Working Group on Coupled Modelling, which is responsible for CMIP, and we thank the climate modeling groups (listed in Table 1 ) for producing and making available their model output. For CMIP, the
U.S. Department of Energy's Program for Climate Model Diagnosis and Intercomparison provides coordinating support and led development of software infrastructure in partnership with the Global Organization for Earth System Science Portals. Finally, we thank all of the BIOME 6000 participants for systematizing the global LGM pollen records. J.S. was supported by NSF Award AGS-1433551, and R.S. and H.L. were supported by NSF Awards AGS-1401400 and AGS-1243204.

\section{APPENDIX}

\section{Responses to Future Warming and $\mathrm{CO}_{2}$ Using the Larger Suite of Models}

Figure A1 shows the CMIP5 future eco-hydrologic projections as in Fig. 1, but for all available models, rather than just those that simulated the LGM. The maps are extremely similar. For the hydrologic variables, the regions of robust change in Fig. A1 are not quite as extensive as in Fig. 1 but still very clear. For photosynthesis, the response in Fig. A1h is even more positive and robust than in Fig. 1h, with no areas of median browning at all. Thus, our results have implications for all CMIP5 models.

\section{REFERENCES}

Adams, J. M., and H. Faure, 1997: Review and atlas of palaeovegetation: Preliminary land ecosystem maps of the world since the Last Glacial Maximum. Oak Ridge National Laboratory, accessed 31 May 2016. [Available online at http:// www.esd.ornl.gov/projects/gen/.]

Albani, S., and Coauthors, 2016: Paleodust variability since the Last Glacial Maximum and implications for iron inputs to the ocean. Geophys. Res. Lett., 43, 3944-3954, doi:10.1002/ 2016GL067911.

Allen, R. G., L. S. Pereira, D. Raes, and M. Smith, 1998: Crop evapotranspiration: Guidelines for computing crop water requirements. Food and Agriculture Organization Irrigation and Drainage Paper 56, 328 pp.

Anderegg, W. R. L., J. A. Berry, D. D. Smith, J. S. Sperry, L. D. L. Anderegg, and C. B. Field, 2012: The roles of hydraulic and carbon stress in a widespread climate-induced forest die-off. Proc. Natl. Acad. Sci. USA, 109, 233-237, doi:10.1073/ pnas.1107891109.

Arnell, N., and Coauthors, 2001: Hydrology and water resources. Climate Change 2001: Impacts, Adaptation and Vulnerability, J. J. McCarthy et al., Eds., Cambridge University Press, 191233.

Arora, V. K., and Coauthors, 2013: Carbon-concentration and carbon-climate feedbacks in CMIP5 Earth system models. J. Climate, 26, 5289-5314, doi:10.1175/JCLI-D-12-00494.1.

Berg, A., and Coauthors, 2016: Land-atmosphere feedbacks amplify aridity increase over land under global warming. Nat. Climate Change, 6, 869-874, doi:10.1038/nclimate3029.

Bigelow, N. H., and Coauthors, 2003: Climate change and Arctic ecosystems: 1 . Vegetation changes north of $55^{\circ} \mathrm{N}$ between the 
Last Glacial Maximum, mid-Holocene, and present. J. Geophys. Res., 108, 8170, doi:10.1029/2002JD002558.

Bonan, G., 2008: Ecological Climatology: Concepts and Applications. 2nd ed. Cambridge University Press, $550 \mathrm{pp}$.

Boucot, A. J., C. Xu, C. R. Scotese, and R. J. Morley, 2013: Phanerozoic Paleoclimate: An Atlas of Lithologic Indicators of Climate. SEPM Concepts in Sedimentology and Paleontology, Vol. 11, Society for Sedimentary Geology, $478 \mathrm{pp}$.

Braconnot, P., S. P. Harrison, M. Kageyama, P. J. Bartlein, V. Masson-Delmotte, A. Abe-Ouchi, B. Otto-Bliesner, and Y. Zhao, 2012: Evaluation of climate models using palaeoclimatic data. Nat. Climate Change, 2, 417-424, doi:10.1038/ nclimate1456.

Bragg, F. J., I. C. Prentice, S. P. Harrison, G. Eglinton, P. N. Foster, F. Rommerskirchen, and J. Rullkötter, 2013: Stable isotope and modelling evidence for $\mathrm{CO}_{2}$ as a driver of glacialinterglacial vegetation shifts in southern Africa. Biogeosciences, 10, 2001-2010, doi:10.5194/bg-10-2001-2013.

Broecker, W., 2010: Long-term water prospects in the western United States. J. Climate, 23, 6669-6683, doi:10.1175/2010JCLI3780.1.

Byrne, M. P., and P. A. O'Gorman, 2015: The response of precipitation minus evapotranspiration to climate warming: Why the "wet-get-wetter, dry-get-drier" scaling does not hold over land. J. Climate, 28, 8078-8092, doi:10.1175/JCLI-D-15-0369.1. , and —, 2016: Understanding decreases in land relative humidity with global warming: Conceptual model and GCM simulations. J. Climate, 29, 9045-9061, doi:10.1175/ JCLI-D-16-0351.1.

Collins, M., and Coauthors, 2013: Long-term climate change: Projections, commitments and irreversibility. Climate Change 2013: The Physical Science Basis, T. F. Stocker et al, Eds., Cambridge University Press, 1029-1136. [Available online at http://www.climatechange2013.org/images/report/WG1AR5_ Chapter12_FINAL.pdf.]

Cook, B. I., J. E. Smerdon, R. Seager, and S. Coats, 2014: Global warming and 21st century drying. Climate Dyn., 43, 2607-2627, doi:10.1007/s00382-014-2075-y.

Dai, A., 2013: Increasing drought under global warming in observations and models. Nat. Climate Change, 3, 52-58, doi:10.1038/nclimate1633.

De Kauwe, M. G., and Coauthors, 2013: Forest water use and water use efficiency at elevated $\mathrm{CO}_{2}$ : A model-data intercomparison at two contrasting temperate forest FACE sites. Global Change Biol., 19, 1759-1779, doi:10.1111/gcb.12164.

Donohue, R. J., M. L. Roderick, T. R. McVicar, and G. D. Farquhar, 2013: Impact of $\mathrm{CO}_{2}$ fertilization on maximum foliage cover across the globe's warm, arid environments. Geophys. Res. Lett., 40, 3031-3035, doi:10.1002/grl.50563.

Elenga, H., and Coauthors, 2000: Pollen-based biome reconstruction for southern Europe and Africa 18,000 yr BP. J. Biogeogr., 27, 621-634, doi:10.1046/j.1365-2699.2000.00430.x.

Feakins, S. J., and P. B. deMenocal, 2010: Global and African regional climate during the Cenozoic. Cenozoic Mammals of Africa, L. Werdelin and W. J. Sanders, Eds., University of California Press, 45-55.

Feng, S., and Q. Fu, 2013: Expansion of global drylands under a warming climate. Atmos. Chem. Phys., 13, 10 081-10 094, doi:10.5194/acp-13-10081-2013.

Frakes, L. A., J. E. Francis, and J. I. Syktus, 1992: Climate Modes of the Phanerozoic. Cambridge University Press, 288 pp.

Fu, Q., and S. Feng, 2014: Responses of terrestrial aridity to global warming. J. Geophys. Res. Atmos., 119, 7863-7875, doi:10.1002/2014JD021608.
L. Lin, J. Huang, S. Feng, and A. Gettelman, 2016: Changes in terrestrial aridity for the period 850-2080 from the Community Earth System Model. J. Geophys. Res. Oceans, 121, 2857-2873, doi:10.1002/jgrc.21405.

Gasse, F., and E. Van Campo, 1998: A 40,000-yr pollen and diatom record from Lake Tritrivakely, Madagascar, in the southern tropics. Quat. Res., 49, 299-311, doi:10.1006/qres.1998.1967.

Gerhart, L. M., and J. K. Ward, 2010: Plant responses to low $\left[\mathrm{CO}_{2}\right]$ of the past. New Phytol., 188, 674-695, doi:10.1111/ j.1469-8137.2010.03441.x.

Greve, P., and S. I. Seneviratne, 2015: Assessment of future changes in water availability and aridity. Geophys. Res. Lett., 42, 5493-5499, doi:10.1002/2015GL064127.

$\longrightarrow$, B. Orlowsky, B. Mueller, J. Sheffield, M. Reichstein, and S. I. Seneviratne, 2014: Global assessment of trends in wetting and drying over land. Nat. Geosci., 7, 716-721, doi:10.1038/ ngeo2247.

Harrison, S. P., and P. J. Bartlein, 2012: Records from the past, lessons for the future: What the palaeo-record implies about mechanisms of global change. The Future of the World's Climate, A. Henderson-Sellers and K. McGuffie, Eds., Elsevier, 403-436.

_ , G. Yu, H. Takahara, and I. C. Prentice, 2001: Palaeovegetation (communications arising): Diversity of temperate plants in East Asia. Nature, 413, 129-130, doi:10.1038/ 35093166

Hegerl, G. C., and Coauthors, 2007: Understanding and attributing climate change. Climate Change 2007: The Physical Science Basis, S. Solomon et al., Eds., Cambridge University Press, 663-745. [Available online at https://www.ipcc.ch/pdf/ assessment-report/ar4/wg1/ar4-wg1-chapter9.pdf.]

Held, I., and B. Soden, 2006: Robust responses of the hydrological cycle to global warming. J. Climate, 19, 5686-5699, doi:10.1175/JCLI3990.1.

Hopcroft, P. O., P. J. Valdes, S. Woodward, and M. M. Joshi, 2015: Last Glacial Maximum radiative forcing from mineral dust aerosols in an Earth system model. J. Geophys. Res. Atmos., 120, 8186-8205, doi:10.1002/2015JD023742.

Jolly, D., and Coauthors, 1998: Biome reconstruction from pollen and plant macrofossil data for Africa and the Arabian Peninsula at 0 and 6000 years. J. Biogeogr., 25, 1007-1027, doi:10.1046/j.1365-2699.1998.00238.x.

Kaplan, J. O., and Coauthors, 2003: Climate change and Arctic ecosystems: 2. Modeling, paleodata-model comparisons, and future projections. J. Geophys. Res., 108, 8171, doi:10.1029/ 2002JD002559.

Marchant, R., and Coauthors, 2009: Pollen-based biome reconstructions for Latin America at 0, 6000 and 18000 radiocarbon years ago. Climate Past, 5, 725-767, doi:10.5194/cp-5-725-2009.

Masson-Delmotte, V., and Coauthors, 2013: Information from paleoclimate archives. Climate Change 2013: The Physical Science Basis, T. F. Stocker et al., Eds., Cambridge University Press, 383-464. [Available online at http://www.ipcc.ch/pdf/ assessment-report/ar5/wg1/WG1AR5_Chapter05_FINAL.pdf.]

McGee, D., W. S. Broecker, and G. Winckler, 2010: Gustiness: The driver of glacial dustiness? Quat. Sci. Rev., 29, 2340-2350, doi:10.1016/j.quascirev.2010.06.009.

Middleton, N., and D. S. G. Thomas, 1997: World Atlas of Desertification. 2nd ed. Wiley, $182 \mathrm{pp}$.

Milly, P. C. D., and K. A. Dunne, 2016: Potential evapotranspiration and continental drying. Nat. Climate Change, 6, 946-949, doi:10.1038/nclimate3046.

Muhs, D. R., 2013: The geologic records of dust in the Quaternary. Aeolian Res., 9, 3-48, doi:10.1016/j.aeolia.2012.08.001. 
Pendergrass, A. G., and D. L. Hartmann, 2014: The atmospheric energy constraint on global-mean precipitation change. J. Climate, 27, 757-768, doi:10.1175/JCLI-D-13-00163.1.

Petit, J. R., and Coauthors, 1999: Climate and atmospheric history of the past 420,000 years from the Vostok ice core, Antarctica Nature, 399, 429-436, doi:10.1038/20859.

Peyron, O., J. Guiot, R. Cheddadi, P. Tarasov, M. Reille, J.-L. de Beaulieu, S. Bottema, and V. Andrieu, 1998: Climatic reconstruction in Europe for 18,000 yr B.P. from pollen data. Quat. Res., 49, 183-196, doi:10.1006/qres.1997.1961.

Pickett, E. J., and Coauthors, 2004: Pollen-based reconstructions of biome distributions for Australia, Southeast Asia and the Pacific (SEAPAC region) at 0,6000 and 18,000 ${ }^{14}$ C yr BP. J. Biogeogr., 31, 1381-1444, doi:10.1111/ j.1365-2699.2004.01001.x.

Prentice, I. C., and S. P. Harrison, 2009: Ecosystem effects of $\mathrm{CO}_{2}$ concentration: Evidence from past climates. Climate Past, $\mathbf{5}$, 297-307, doi:10.5194/cp-5-297-2009.

_ _ J. Guiot, and S. P. Harrison, 1992: Mediterranean vegetation, lake levels, and palaeoclimate at the Last Glacial Maximum. Nature, 360, 658-660, doi:10.1038/360658a0.

,-- , B. Huntley, D. Jolly, and R. Cheddadi, 1996: Reconstructing biomes from palaeoecological data: A general method and its application to European pollen data at 0 and 6 ka. Climate Dyn., 12, 185-194, doi:10.1007/BF00211617.

— , and Coauthors, 2000: Mid-Holocene and Glacial-Maximum vegetation geography of the northern continents and Africa. J. Biogeogr., 27, 507-519, doi:10.1046/j.1365-2699.2000.00425.x.

- S. P. Harrison, and P. J. Bartlein, 2011: Global vegetation and terrestrial carbon cycle changes after the last ice age. New Phytol., 189, 988-998, doi:10.1111/j.1469-8137.2010.03620.x.

Roderick, M. L., F. Sun, W. H. Lim, and G. D. Farquhar, 2014: A general framework for understanding the response of the water cycle to global warming over land and ocean. Hydrol. Earth Syst. Sci., 18, 1575-1589, doi:10.5194/hess-18-1575-2014.

— P. Preve, and G. D. Farquhar, 2015: On the assessment of aridity with changes in atmospheric $\mathrm{CO}_{2}$. Water Resour. Res., 51, 5450-5463, doi:10.1002/2015WR017031.

Scheff, J., 2014: Understanding the responses of precipitation, evaporative demand, and terrestrial water availability to planetary temperature in climate models. Ph.D. thesis, University of Washington, $199 \mathrm{pp}$. [Available online at http://hdl.handle.net/1773/26158.]

_ , and D. M. W. Frierson, 2014: Scaling potential evapotranspiration with greenhouse warming. J. Climate, 27, 1539-1558, doi:10.1175/JCLI-D-13-00233.1.

— , and —, 2015: Terrestrial aridity and its response to greenhouse warming across CMIP5 climate models. J. Climate, 28, 5583-5600, doi:10.1175/JCLI-D-14-00480.1.

Seager, R., N. Naik, and G. A. Vecchi, 2010: Thermodynamic and dynamic mechanisms for large-scale changes in the hydrological cycle in response to global warming. J. Climate, 23, 4651-4668, doi:10.1175/2010JCLI3655.1.

Sellers, P., and Coauthors, 1996: Comparison of radiative and physiological effects of doubled atmospheric $\mathrm{CO}_{2}$ on climate. Science, 271, 1402-1406, doi:10.1126/science.271.5254.1402.

Shao, P., X. Zeng, K. Sakaguchi, R. K. Monson, and X. Zeng, 2013: Terrestrial carbon cycle: Climate relations in eight CMIP5 Earth system models. J. Climate, 26, 8744-8764, doi:10.1175/ JCLI-D-12-00831.1.

Sherwood, S., and Q. Fu, 2014: A drier future? Science, 343, 737739, doi:10.1126/science.1247620.
Sloan, L. C., J. C. G. Walker, T. C. Moore, D. K. Rea, and J. C. Zachos, 1992: Possible methane-induced polar warming in the early Eocene. Nature, 357, 320-322, doi:10.1038/357320a0.

Stephens, G. L., and Y. Hu, 2010: Are climate-related changes to the character of global-mean precipitation predictable? Environ. Res. Lett., 5, 025209, doi:10.1088/1748-9326/5/2/025209.

Swann, A. L. S., F. M. Hoffman, C. D. Koven, and J. T. Randerson, 2016: Plant responses to increasing $\mathrm{CO}_{2}$ reduce estimates of climate impacts on drought severity. Proc. Natl. Acad. Sci. USA, 113, 10 019-10 024, doi:10.1073/pnas.1604581113.

Takahara, H., S. Sugita, S. P. Harrison, N. Miyoshi, Y. Morita, and T. Uchiyama, 2000: Pollen-based reconstructions of Japanese biomes at 0, 6000 and $18,000{ }^{14} \mathrm{C}$ yr BP. J. Biogeogr., 27, 665683, doi:10.1046/j.1365-2699.2000.00432.x.

Tarasov, P. E., and Coauthors, 1998: Present-day and midHolocene biomes reconstructed from pollen and plant macrofossil data from the former Soviet Union and Mongolia. J. Biogeogr., 25, 1029-1053, doi:10.1046/ j.1365-2699.1998.00236.x.

, and Coauthors, 2000: Last Glacial Maximum biomes reconstructed from pollen and plant macrofossil data from northern Eurasia. J. Biogeogr., 27, 609-620, doi:10.1046/ j.1365-2699.2000.00429.x.

Taylor, D. M., 1990: Late Quaternary pollen records from two Ugandan mires: Evidence for environmental change in the Rukiga Highlands of southwest Uganda. Palaeogeogr. Palaeoclimatol. Palaeoecol., 80, 283-300, doi:10.1016/ 0031-0182(90)90138-W.

Taylor, K. E., R. J. Stouffer, and G. A. Meehl, 2012: An overview of CMIP5 and the experiment design. Bull. Amer. Meteor. Soc., 93, 485-498, doi:10.1175/BAMS-D-11-00094.1.

Thompson, R. S., and K. H. Anderson, 2000: Biomes of western North America at 18,000, 6000 and $0{ }^{14} \mathrm{C}$ yr BP reconstructed from pollen and packrat midden data. J. Biogeogr., 27, 555584, doi:10.1046/j.1365-2699.2000.00427.x.

Ullman, D. J., A. N. LeGrande, A. E. Carlson, F. S. Anslow, and J. M. Licciardi, 2014: Assessing the impact of Laurentide ice sheet topography on glacial climate. Climate Past, 10, 487-507, doi:10.5194/cp-10-487-2014.

Valipour, M., M. A. G. Sefidkouhi, and M. Raeini-Sarjaz, 2017: Selecting the best model to estimate potential evapotranspiration with respect to climate change and magnitudes of extreme events. Agric. Water Manage., 180, 50-60, doi:10.1016/j.agwat.2016.08.025.

Williams, J. W., T. Webb, P. H. Richard, and P. Newby, 2000: Late Quaternary biomes of Canada and the eastern United States. J. Biogeogr., 27, 585-607, doi:10.1046/j.1365-2699.2000.00428.x.

Williams, M., 2014: Climate Change in Deserts: Past, Present and Future. Cambridge University Press, 629 pp.

Yu, G., I. C. Prentice, S. P. Harrison, and X. Sun, 1998: Pollen-based biome reconstructions for China at 0 and 6000 years. J. Biogeogr., 25, 1055-1069, doi:10.1046/j.1365-2699.1998.00237.x.

, and Coauthors, 2000: Palaeovegetation of China: A pollen data-based synthesis for the mid-Holocene and Last Glacial Maximum. J. Biogeogr., 27, 635-664, doi:10.1046/ j.1365-2699.2000.00431.x.

Zhao, T., and A. Dai, 2015: The magnitude and causes of global drought changes in the twenty-first century under a lowmoderate emissions scenario. J. Climate, 28, 4490-4512, doi:10.1175/JCLI-D-14-00363.1.

— projections of drought. Part II: Model-simulated historical and future drought changes. Climatic Change, doi:10.1007/ s10584-016-1742-x, in press. 